\title{
Present-day radiative effect from radiation-absorbing aerosols in snow
}

\author{
Paolo Tuccella $^{1,2}$, Giovanni Pitari ${ }^{1}$, Valentina Colaiuda ${ }^{1,2}$, Edoardo Raparelli $^{2,3}$, and Gabriele Curci ${ }^{1,2}$ \\ ${ }^{1}$ Department of Physical and Chemical Sciences, University of L'Aquila, 67100 L'Aquila, Italy \\ ${ }^{2}$ Center of Excellence in Telesensing of Environment and Model Prediction of Severe Events (CETEMPS), \\ University of L'Aquila, 67100 L'Aquila, Italy \\ ${ }^{3}$ Department Information Engineering, Electronics and Telecommunications, \\ Sapienza Università di Roma, 00185 Rome, Italy
}

Correspondence: Paolo Tuccella (paolo.tuccella@aquila.infn.it, paolo.tuccella@univaq.it)

Received: 11 June 2020 - Discussion started: 13 August 2020

Revised: 17 March 2021 - Accepted: 3 April 2021 - Published: 6 May 2021

\begin{abstract}
Black carbon (BC), brown carbon $(\mathrm{BrC})$, and soil dust are the most important radiation-absorbing aerosols (RAAs). When RAAs are deposited on the snowpack, they lower the snow albedo, causing an increase in the solar radiation absorption. The climatic impact associated with the snow darkening induced by RAAs is highly uncertain. The Intergovernmental Panel on Climate Change (IPCC) Special Report on the Ocean and Cryosphere in a Changing Climate (SROCC) attributes low and medium confidence to radiative forcing (RF) from $\mathrm{BrC}$ and dust in snow, respectively. Therefore, the contribution of anthropogenic sources and carbonaceous aerosols to RAA RF in snow is not clear. Moreover, the snow albedo perturbation induced by a single RAA species depends on the presence of other light-absorbing impurities contained in the snowpack. In this work, we calculated the present-day RF of RAAs in snow starting from the deposition fields from a 5-year simulation with the GEOS-Chem global chemistry and transport model. RF was estimated taking into account the presence of $\mathrm{BC}, \mathrm{BrC}$, and mineral soil dust in snow, simultaneously. Modeled BC and black carbon equivalent (BCE) mixing ratios in snow and the fraction of light absorption due to non-BC compounds ( $\left.f_{\text {non-BC }}\right)$ were compared with worldwide observations. We showed that BC, BCE, and $f_{\text {non-BC, }}$, obtained from deposition and precipitation fluxes, reproduce the regional variability and order of magnitude of the observations. Global-average all-sky total RAA-, BC, BrC-, and dust-snow RF were 0.068, 0.033, 0.0066, and $0.012 \mathrm{~W} \mathrm{~m}^{-2}$, respectively. At a global scale, non-BC compounds accounted for $40 \%$ of RAA-snow RF, while anthro-
\end{abstract}

pogenic RAAs contributed to the forcing for $56 \%$. With regard to non-BC compounds, the largest impact of $\mathrm{BrC}$ has been found during summer in the Arctic $\left(+0.13 \mathrm{~W} \mathrm{~m}^{-2}\right)$. In the middle latitudes of Asia, the forcing from dust in spring accounted for $50 \%\left(+0.24 \mathrm{~W} \mathrm{~m}^{-2}\right)$ of the total RAA RF. Uncertainties in absorbing optical properties, RAA mixing ratio in snow, snow grain dimension, and snow cover fraction resulted in an overall uncertainty of $-50 \% /+61 \%$, $-57 \% /+183 \%,-63 \% /+112 \%$, and $-49 \% /+77 \%$ in BC, BrC-, dust-, and total RAA-snow RF, respectively. Uncertainty upper bounds of $\mathrm{BrC}$ and dust were about 2 and 3 times larger than the upper bounds associated with BC. Higher BrC and dust uncertainties were mainly due to the presence of multiple absorbing impurities in the snow. Our results highlight that an improvement of the representation of RAAs in snow is desirable, given the potential high efficacy of this forcing.

\section{Introduction}

In the last decades, many studies have recognized the contribution of radiation-absorbing aerosols (RAAs) to climate warming, in particular black carbon (BC), brown carbon $(\mathrm{BrC})$, and dust, once deposited on the snow and ice pack (Hansen and Nazarenko, 2004; Hansen et al., 2005, 2007; Flanner et al., 2007, 2009; Bond et al., 2013; Boucher et al., 2013; Lin et al., 2014; Pitari et al., 2015a; Skiles et al., 2018). Observations show that the extent of snow coverage is de- 
clining due to global warming (Sturm et al., 2017). RAA deposition on snowy surfaces results in an enhancement of the absorbed solar radiation in snow due to the snowpack albedo reduction. This process increases melting and therefore reduces the snow duration. As a result, the alteration of runoff timing and magnitude due to the climate warming is amplified (e.g., Coppola et al., 2014), with significant impact on water resources (e.g., Painter et al., 2010; Skiles et al., 2012; Wu et al., 2018). Forcing efficacy by RAAs in snow is about 3 times larger than the forcing that results from carbon dioxide $\left(\mathrm{CO}_{2}\right)$ (Flanner et al., 2007; Bond et al., 2013; Boucher et al., 2013). However, the climatic effect associated with RAAs in snow is still highly uncertain.

$\mathrm{BC}$ is emitted by the incomplete combustion of fossil fuel (FF), biofuel (BF), and biomass burning (BB) (Bond et al., 2013) and is characterized by high efficiency in absorbing the incoming solar radiation (Bond et al., 2013; Boucher et al., 2013). Current estimates suggest $B C$ as the second most important climate forcing species after carbon dioxide (Gustafsson and Ramanathan, 2016). A large regional variability in $\mathrm{BC}$ mixing ratio in snow, ranging over 4 orders of magnitude, has been found by Warren (2019). As an example, Doherty et al. (2010) reported values of $1-4 \mathrm{ng} \mathrm{g}^{-1}$ in Greenland ice sheets, $4-10 \mathrm{ng} \mathrm{g}^{-1}$ in the Arctic Ocean, $8-14 \mathrm{ng} \mathrm{g}^{-1}$ in Canada, and up to $10-60$ and $20-60 \mathrm{ng} \mathrm{g}^{-1}$ in the Russian Arctic and Scandinavia. As for middle latitudes, BC mixing ratio in snow was found to be in the range of $5-70 \mathrm{ng} \mathrm{g}^{-1}$ in central North America (Doherty et al., 2014) and 20-600 and 30-2000 $\mathrm{ng} \mathrm{g}^{-1}$ in northwestern and northeastern China (Ye et al., 2012; Wang et al., 2013). The lowest BC mixing ratios in snow were found in Antarctica, being on the order of tenths of a nanogram per gram (Warren and Clark, 1990; Grenfell et al., 1994; Zatko and Warren, 2015). Currently, the best estimation of the present-day radiative forcing (RF) by $\mathrm{BC}$ in snow and in melting snow-free sea ice is $+0.040 \mathrm{~W} \mathrm{~m}^{-2}\left(+0.01 /+0.09 \mathrm{~W} \mathrm{~m}^{-2}\right)$ and $+0.012 \mathrm{~W} \mathrm{~m}^{-2}$ $\left(+0.008 /+0.017 \mathrm{~W} \mathrm{~m}^{-2}\right)$ (Bond et al., 2013), respectively. The change in the surface temperature global average resulting from the RF exerted by $\mathrm{BC}$ in snow ranges from +0.06 to $+0.20 \mathrm{~K}$, while equilibrium change in Arctic surface temperature is estimated to be in the range of $0.50-1.6 \mathrm{~K}$ (Bond et al., 2013; Flanner et al., 2007).

RAAs in snow are not only represented by $\mathrm{BC}$ since the presence of both soil dust and absorbing organic aerosol (OA) has been observed in the snowpack. Measurements across the Arctic and central North America suggested that $20 \%-50 \%$ of the sunlight absorption in the snowpack is due to non-BC RAA particles (Doherty et al., 2010, 2014), while in the Qilian Mountains the snow particulate absorption is dominated by non-BC compounds (around $100 \%$ ), according to Wang et al. (2013).

$\mathrm{BrC}$ is defined as the radiation-absorbing fraction of $\mathrm{OA}$ (Andreae and Gelencsér, 2006; Laskin et al., 2015); it absorbs shortwave radiation with wavelengths less than $400 \mathrm{~nm}$ (Lukács et al., 2007; Alexander et al., 2008; Chen and Bond,
2010; Arola et al., 2011; Kirchstetter and Thatcher, 2012). Sources of such absorbing organic matter are still uncertain; observations indicate that $\mathrm{BrC}$ is mainly produced by $\mathrm{BF}$ combustion, $\mathrm{BB}$, and aging of secondary organic aerosol (SOA) (Bones et al., 2010; Hecobian et al., 2010; Arola et al., 2011; Updyke et al., 2012; Lambe et al., 2013; Laskin et al., 2015; Guang-Ming et al., 2016), while other sources are represented by some aqueous-phase chemical reactions in clouds (Zhang et al., 2017). BrC treatment is poor in current atmospheric models due to lack of mass and absorption observations. For this reason, OA is commonly treated as scattering, and only few studies have investigated the climatic impact of $\mathrm{OA}$ as $\mathrm{BrC}$ (Wang et al., 2014; Lin et al., 2014; Saleh et al., 2015; Jo et al., 2016; Wang et al., 2018; Brown et al., 2018; Tuccella et al., 2020). The Intergovernmental Panel on Climate Change (IPCC) 5th Assessment Report (AR5) did not analyze the absorption of $\mathrm{BrC}$ in snow; however, this aspect was discussed in the IPCC Special Report on the Ocean and Cryosphere in a Changing Climate (SROCC) (Meredith et al., 2019). According to the SROCC, there is low confidence in the attribution of $\mathrm{RF}$ of $\mathrm{BrC}$ in snow. To the best of our knowledge, the global RF due to the change in OA in snow from preindustrial times was calculated by Lin et al. (2014) only, who reported estimated values ranging from +0.0011 to $+0.0031 \mathrm{~W} \mathrm{~m}^{-2}$.

Soil dust is emitted from arid and semi-arid regions (Choobari et al., 2013) and from soils disturbed by anthropogenic activities (Tegen et al., 2004; Ginoux et al., 2012). The largest amount of dust in snow was found downwind from large sources (Skiles et al., 2018). Soil dust is much less absorbing than $\mathrm{BC}$; however, it may dominate the RF in snow when present in very high concentrations. However, dust emissions have increased (Mahowald et al., 2010), and the dust absorption has a non-negligible effect on springtime Eurasian snow (Flanner et al., 2009; Skiles et al., 2018). Also in this case, AR5 did not assess the radiative forcing of dust in snow; however, the SROCC attributes medium confidence to snow darkening from dust (Meredith et al., 2019).

Some studies have shown that the presence of non-BC that absorbs impurities in snow reduces the influence of BC, especially in regions located downwind from large dust sources (Bond et al., 2013). Flanner et al. (2009) found that the dust deposition on the snowpack decreases the BC RF by $25 \%$, and, according to Bond et al. (2013), the role of dust in reducing BC RF ranges from $10 \%$ to $40 \%$. Dang et al. (2017) reported regionally averaged albedo reductions due to RAAs of 0.009, 0.012, and 0.077 for fresh snow in the Arctic, North America, and China, respectively. Moreover, in the same regions, the albedo reductions caused by $\mathrm{BC}$ only are 0.005 , 0.005 , and 0.031 . The same authors have also estimated an increase of $20 \%-40 \%$ in albedo perturbation in snow that did not contain non-BC RAAs. On the other hand, the presence of different light-absorbing impurities may also impact the BrC RF. Beres et al. (2020) found that the BrC deposition onto pure snow resulted in a local instantaneous RF more 
than twice as large with respect to a case with dark snowpack. These results highlight the importance of taking into account the concentrations in snow of $\mathrm{BC}, \mathrm{BrC}$, and mineral soil dust simultaneously.

RF by snow RAAs is also affected by other uncertainties related to emissions, snow aging, scavenging of the impurities in melting snow, parameterization for snow cover fraction (SCF), and absorption optical properties. The overall error associated with $\mathrm{BC} \mathrm{RF}$ due to these single uncertainties is $-73 \% /+117 \%$ (Flanner et al., 2007, 2009; Bond et al., 2013). To the best of our knowledge, there are no studies which quantify all these uncertainties for $\mathrm{BrC}$ and soil dust at a global scale.

In this study, we performed a multi-year simulation of the RAA mass concentration with the global chemical and transport model GEOS-Chem (Bey et al., 2001). RAA mass and their optical properties have been simulated using the most recent updates in terms of aging, size distribution, and absorption optical properties, inferred from observational constraints following our previous work (Tuccella et al., 2020). Starting from the GEOS-Chem output, we have diagnosed the mass mixing ratios of RAAs in snow and, subsequently, calculated the RF for different RAA species. In Sect. 2, we provide the description of modeling tools used in this study. In Sect. 3, the modeled RAA content in snow is compared with the available observations, and the associated RF is, therefore, calculated, taking into account the simultaneous presence of $\mathrm{BC}, \mathrm{BrC}$, and dust in the snow. Moreover, seasonal and regional differences in the RF of each species are explored. We also provide insights about the contribution of anthropogenic and carbonaceous compounds to the total RF. Finally, we discuss the uncertainties in modeling this kind of forcing associated with the assumptions of RAA optical properties, RAA mixing ratio uncertainty, snow aging, and snow cover fraction. The conclusions are given in Sect. 4 .

\section{Methods}

\subsection{GEOS-Chem model}

Aerosol mass concentration was simulated with the GEOSChem global chemical and transport model, v11-01 (Bey et al., 2001, with updates documented at http://www. geos-chem.org, last access: 3 May 2021). Five years (2010 to 2014) were simulated by the model, with a grid resolution of $4^{\circ} \times 5^{\circ}$ and 47 vertical levels up to $0.01 \mathrm{hPa}$. Herein, GEOSChem was driven by Modern Era Retrospective-analysis for Research and Application version 2 (MERRA2) with assimilation of meteorological data from the Global Modeling and Assimilation Office Goddard Earth Observing System (Rienecker et al., 2011).

$\mathrm{BC}, \mathrm{BrC}$, and dust are treated as described in Tuccella et al. (2020). BC emissions and aging were considered to be source-dependent as in Wang et al. (2014, 2018), and hydrophobic and hydrophilic $\mathrm{BC}$ was tracked for $\mathrm{FF}, \mathrm{BF}$, and $\mathrm{BB}$ sources. BrC was inferred from primary organic aerosols (POAs) and secondary organic aerosols, while dust mass concentration was simulated with a sectional approach and emitted dust size distribution following the function of Kok (2011). More details about GEOS-Chem parameterizations and RAA treatment are provided in the Supplement.

\subsection{Snow albedo perturbation}

The snow albedo reduction by RAAs was calculated through the parameterization of Dang et al. (2015), which is based on the Mie theory for spherical particles (Mie, 1908) and assumes that snow impurities are externally mixed with snow grains. In this scheme, the snow albedo reduction by $\mathrm{BC}$ is parameterized for three broadbands - all-wave, visible (VIS), and near-infrared (NIR) - by using a quadratic or cubic polynomial in the $\mathrm{BC}$ mixing ratio, whose coefficients are themselves quadratic in snow grain size $\left(R_{\mathrm{e}}\right)$. It should be noted that the parameterization of Dang et al. (2015) was formulated assuming a size distribution and a complex refractive index for BC. Nevertheless, it can be used for BC particles with different size and refractive index by scaling the mass mixing ratio with the ratio between the mass absorption coefficient (MAC) based on our own assumptions and the coefficient used in Dang et al. (2015). The MAC of given aerosol species at a given wavelength $\lambda$ is defined as

$\operatorname{MAC}_{\lambda}=\frac{3 Q_{\text {ext }, \lambda}\left(1-\omega_{\lambda}\right)}{4 \rho R_{\text {eff }}}$,

where $Q_{\text {ext }}$ is the extinction efficiency, $\omega$ the single scattering albedo, $R_{\text {eff }}$ the particle effective radius, and $\rho$ the particle density. In our work, the contribution to snow albedo reduction from soil dust and $\mathrm{BrC}$ was taken into account through the concept of black carbon equivalent (BCE) (Grenfell et al., 2011), following Ward et al. (2018):

$$
\begin{aligned}
\mathrm{BCE} & =\mathrm{BC}+\sum_{i=1}^{4} \frac{\mathrm{MAC}_{\text {Dust }, i}}{\mathrm{MAC}_{\mathrm{BC}}}\left[\text { Dust }_{i}\right] \\
& +\frac{\mathrm{MAC}_{\mathrm{BrC}} \mathrm{BF}_{\mathrm{BF}}}{\mathrm{MAC}_{\mathrm{BC}}}\left[\mathrm{BrC}_{\mathrm{BF}}\right]+\frac{\mathrm{MAC}_{\mathrm{BrC}} \mathrm{BB}_{\mathrm{B}}}{\mathrm{MAC}_{\mathrm{BC}}}\left[\mathrm{BrC}_{\mathrm{BB}}\right] \\
& +\frac{\mathrm{MAC}_{\mathrm{BrC}} \mathrm{SOA}}{\mathrm{MAC}_{\mathrm{BC}}}\left[\mathrm{BrC}_{\mathrm{SOA}}\right],
\end{aligned}
$$

[BC] being the $\mathrm{BC}$-snow mixing ratio; [Dust ${ }_{i}$ ] the mixing ratio of dust in the dimensional $i$ th bin; and $\left[\mathrm{BrC}_{\mathrm{BF}}\right],\left[\mathrm{BrC}_{\mathrm{BB}}\right]$, and $\left[\mathrm{BrC}_{\mathrm{SOA}}\right]$ the $\mathrm{BrC}$ mixing ratios from $\mathrm{BF}, \mathrm{BB}$, and $\mathrm{SOA}$ sources, respectively. Once the BCE is calculated, the snow albedo reduction from all absorbing impurities can be estimated with the parameterization for BC proposed by Dang et al. (2015). It should be noted that the MACs that appear in the latter equation are spectrally averaged over an incident solar spectrum, which is characteristic of summer highlatitude conditions. MACs adopted in this work are discussed in the next subsections. 
Dang et al. (2015) also provided a scheme for the albedo reduction in snow containing dust particles, gathered through an estimation of the BCE. However, this parameterization is not used in our work for the following reasons: first of all, the scheme is based on assumptions about the refractive index and size distribution. In particular, in the Dang's scheme a single log-normal mode for long-range-transported dust is adopted, while in our model, dust size distribution evolves over time and is not log-normal. Secondly, our simulations included the coarsest dust particles found near the sources, and this aspect could not be well represented by the size distribution adopted by Dang et al. (2015).

Snow albedo is sensitive to grain size, which depends on snow aging processes (Flanner and Zender, 2006; Flanner et al., 2007). Many studies have considered $R_{\mathrm{e}}$ to be a constant, while only few works used a physical model to calculate the $R_{\mathrm{e}}$ growth (Bond et al., 2013). Uncertainties in $R_{\mathrm{e}}$ resulted in an error of $-42 \% /+58 \%$ in RF estimation (Flanner et al., 2007). For this reason and in order to take into account $R_{\mathrm{e}}$ seasonal and geographical variability, we used the exponential relationship proposed by Zhao et al. (2013) to calculate $R_{\mathrm{e}}$, starting from the snow albedo inferred from MERRA2 reanalysis. It should be noted that this is a rough approximation since the relationship of Zhao et al. (2013) was based on the snow reflectance measured near $1030 \mathrm{~nm}$, while we use the snow broadband albedo in our work and experiment. Moreover, the relationship derived from the snow fields of the Heihe River Basin (China) could be inconsistent in other regions.

Finally, impurity mixing ratios in snow were calculated as the ratio between the deposition fluxes of $\mathrm{BC}$, dust, and $\mathrm{BrC}$ simulated by GEOS-Chem and MERRA2 total precipitation flux (Kopacz et al., 2011; He et al., 2014). It should be highlighted that the impurity content in snow is not only determined by the accumulation rate from deposition processes, but it is also a function of the scavenged fraction of impurities by melting snow. According to Flanner et al. (2007), uncertainties in the scavenged fraction generate an error in BC RF estimation ranging between $-31 \%$ and $+8 \%$.

\subsection{Radiation-absorbing aerosol optical properties}

In this work, we used the same set of optical properties for RAAs employed by Tuccella et al. (2020). The size distribution for BC is source-dependent according to Wang et al. (2018). The geometrical median radius was fixed to 30 and $70 \mathrm{~nm}$ for FF and BF-BB black carbon, while the standard deviations were 1.4 and 1.6, respectively. Following the recommendation of Bond and Bergstrom (2006), the applied refractive index was $1.95-0.79 i$. The $\mathrm{BC}$ density was assumed to be $1.8 \mathrm{~g} \mathrm{~cm}^{-3}$. Using the Mie theory (Mie, 1908), the resulting MACs at $550 \mathrm{~nm}$ were 6.3 and $6.2 \mathrm{~m}^{2} \mathrm{~g}^{-1}$ for FF and BF-BB BC, respectively.

The geometrical median radius, standard deviation and density of $\mathrm{BrC}$ are $90 \mathrm{~nm}, 1.6$, and $1.3 \mathrm{~g} \mathrm{~cm}^{-3}$, respectively
(Wang et al., 2018). The imaginary part of the $\mathrm{BrC}$ refractive index has been inferred starting from the $\mathrm{MAC}$ of $\mathrm{BF}$ and $\mathrm{BB}$ absorbing OA reported by Wang et al. (2018). More details about this calculation are provided in the Supplement. The resulting $\mathrm{MAC}_{\mathrm{BrC}}$ values at $440 \mathrm{~nm}$ were 1.56 for $\mathrm{BF}$ and 3.08 and $0.92 \mathrm{~m}^{2} \mathrm{~g}^{-1}$ for fresh and aged BB. Two different $\mathrm{MAC}_{\mathrm{BrC}}$ values for freshly emitted and aged $\mathrm{BB}$ were used with the aim of taking into account the blanching process of aged plumes due to the photochemical aging (Forrister et al., 2015). A $M_{A C} C_{B r C}$ of $0.3 \mathrm{~m}^{2} \mathrm{~g}^{-1}$ at $440 \mathrm{~nm}$ was assigned to BrC-SOA, as reported in Wang et al. (2014).

Dust optical properties were also inferred as in our previous work (Tuccella et al., 2020). GEOS-Chem simulates the dust size distribution over four dimensional bins (see Sect. 2.1); however, the finer bin was split into four bins for optical calculations, as in Ridley et al. (2012). The refractive index for mineral dust particles was derived from the dataset provided by Petzold et al. (2009). Under these assumptions, Mie calculation indicates a MAC at $550 \mathrm{~nm}$ of 0.057 and $0.048 \mathrm{~m}^{2} \mathrm{~g}^{-1}$ for size ranges of $0.36-0.6$ and $4.4-$ $6.0 \mu \mathrm{m}$, which are representative of the dust particles lying far and close to the sources, respectively.

\subsection{Numerical experiments}

We carried out a series of numerical experiments in order to study the sensitivity of RAA-snow RF due to (i) the simultaneous presence of several light-absorbing impurities, (ii) their absorbing optical properties, (iii) their emissions and mixing ratios in snow, (iv) snow grain size, and (v) snow coverage fraction. The list of our experiments is reported in Table 1.

The first simulation performed represented our reference case (CTRL), where a simultaneous presence of BC and $\mathrm{BrC}$ is considered in the snow. The absorption enhancement $\left(E_{\text {abs }}\right)$ of BC due to the "lensing effect" (Lesins et al., 2002), caused by coating of non-absorbing material, was taken into account, increasing the MAC of aged (hydrophilic) BC by a factor of 1.5, as recommended by Bond et al. (2013). We considered the CTRL simulation to be the "central" (or "mid") absorption scenario. MACs averaged in the VIS are listed in Table 2, while those adopted for NIR are reported in Table S1 in the Supplement.

In the second simulation, the RF of each single species at a time (OSPT) in snow was calculated. The experiment main purpose was to test how much the presence of more RAAs in snow affects the RF of a single species.

The six perturbed experiments were aimed at evaluating the sensitivity of RF to the assumed absorption aerosol properties. For these experiments, we defined a "high" and a "low" absorption scenario for absorbing aerosol species. Estimation of coated $E_{\mathrm{abs}}$ is highly uncertain; recent studies have found values above the most accepted value of 1.5. Tuccella et al. (2020) reported values in the range of 1.7-1.9 for $\mathrm{BC}$ coated by a non-absorbing shell. According to the same 
Table 1. Summary of the numerical experiments.

\begin{tabular}{|c|c|}
\hline Experiment & Description \\
\hline $\mathrm{CTRL}^{1}$ & Control run, reference scenario; mid-absorption \\
\hline OSPT $^{1}$ & RF calculated separately for each RAA \\
\hline $\mathrm{BC}-\mathrm{H}^{1}$ & High absorption, aged $\mathrm{BC} E_{\mathrm{abs}}=1.9$ \\
\hline BC-L $\mathrm{L}^{1}$ & Low absorption, aged $\mathrm{BC} E_{\mathrm{abs}}=1.1$ \\
\hline $\mathrm{BrC}-\mathrm{H}^{1}$ & High absorption, no blanching for aged $\mathrm{BB} \mathrm{BrC}$ \\
\hline $\mathrm{BrC}-\mathrm{L}^{1}$ & Low absorption, blanching for aged $\mathrm{BF} \mathrm{BrC}$ \\
\hline DUST-H $^{1}$ & High absorption, dust refractive index from Wagner et al. (2012) \\
\hline DUST-L $^{1}$ & Low absorption, dust refractive index from Sinyuk et al. (2003) \\
\hline BCE-H ${ }^{2}$ & BCE doubled \\
\hline BCE-L ${ }^{2}$ & BCE halved \\
\hline $\mathrm{Re}-\mathrm{H}^{2}$ & Snow grain size multiplied by 2 \\
\hline $\mathrm{Re}-\mathrm{L}^{2}$ & Snow grain size divided by 2 \\
\hline $\mathrm{SCF}-\mathrm{H}^{2}$ & Snow coverage fraction increased by 1.5 \\
\hline SCF-L ${ }^{2}$ & Snow coverage fraction decreased by 1.5 \\
\hline
\end{tabular}

Table 2. Summary of the MACs in the visible band ${ }^{1}$ used in the experiments. The units are in $\mathrm{m}^{2} \mathrm{~g}^{-1}$.

\begin{tabular}{lrrrr}
\hline \multirow{2}{*}{ Experiment } & \multicolumn{4}{c}{ MAC adopted for each radiation-absorbing aerosol species } \\
\cline { 2 - 5 } & Fresh FF BC & Aged FF BC & Fresh BF-BB BC & Aged BF-BB BC \\
\hline CTRL & 6.5 & 9.8 & 6.2 & 9.3 \\
BC-H & 6.5 & 12.4 & 6.2 & 11.8 \\
BC-L & 6.5 & 7.2 & 6.2 & 6.8 \\
\hline & Fresh BF BrC & Aged BF BrC & Fresh BB BrC & Aged BB BrC \\
\hline CTRL & 1.1 & 1.1 & 1.7 & 0.71 \\
BrC-H & 1.1 & 1.1 & 1.7 & 1.7 \\
BrC-L & 1.1 & 0.46 & 1.7 & 0.71 \\
\hline & Dust $0.36-0.6$ & Dust 2.6-3.6 & Dust 4.4-6.0 & Dust 7.0-12.0 \\
\hline CTRL & 0.085 & 0.059 & 0.048 & 0.039 \\
DUST-H & 0.14 & 0.086 & 0.067 & 0.052 \\
DUST-L & 0.037 & 0.029 & 0.025 & 0.021 \\
\hline
\end{tabular}

${ }^{1}$ MACs reported here are spectrally averaged between $0.3-0.7 \mu \mathrm{m}$ over an incident solar spectrum characteristic of summer high-latitude conditions. ${ }^{2}$ The experiment list is reported in Table 1.

authors, $E_{\text {abs }}$ is $2.8-3.4$ for BC coated by an absorbing shell (brown carbon). Curci et al. (2019) also estimated similar values. On the other hand, $E_{\text {abs }}$ values could be lower than 1.5. As an example, Cappa et al. (2012) have observed very low values for $E_{\text {abs }}$ (about 1.1). As a consequence, we applied $E_{\text {abs }}$ of 1.9 and 1.1 for the BC "high-absorption" (BC$\mathrm{H})$ and "low-absorption" (BC-L) scenarios, respectively.

MAC adopted for $\mathrm{BrC}$ has been optimized with regional observations in the United States (Wang et al., 2018); therefore, assumed values and estimation may be inconsistent worldwide. MACs used for aged $\mathrm{BB} \mathrm{BrC}$ were deduced from a limited dataset (Wang et al., 2016) that was not able to provide the most required constraints on the photochemical whitening processes (Wang et al., 2018). Moreover, it is not clear if the blanching processes affect the $\mathrm{BF} \mathrm{BrC}$. For this reason, two extreme conditions for $\mathrm{BrC}$ absorption have been tested. In detail, a no-whitening process for aged $\mathrm{BB} \mathrm{BrC}$ was assumed in the high-absorption scenario $(\mathrm{BrC}-\mathrm{H})$, while the whitening of $\mathrm{BF} \mathrm{BrC}$ is considered in the low-absorption scenario (BrC-L). In the latter one, we assumed that the MAC of aged biofuel $\mathrm{BrC}$ is reduced by a factor of 2.34 with respect to the CTRL run.

Soil dust absorption and its climatic impact strongly depend on the imaginary part of the refractive index (Pitari et al., 2015b; Tuccella et al., 2020), which is determined by the mineral composition of soil in the source region. Herein, 
we explore the sensitivity of dust absorption in the snow due to the refractive index. In particular, the dataset of Wagner et al. (2012) was exploited for the high-absorption simulation (DUST-H), while the refractive index from Sinyuk et al. (2003) was used in the low-absorption experiment (DUST-L). As shown in Table 2, the considered dust size ranges of MACs are larger by a factor of up to 3.5 in DUST$\mathrm{H}$ with respect to CTRL. By contrast, MACs of DUST-L are lower by a factor of up to a 1.6 with respect to the reference simulation.

Two of the perturbed experiments were aimed at evaluating the sensitivity of RAA-snow RF to their concentration in the snowpack. The mixing ratio of absorbing impurities in the snow depends on many factors, such as emissions, deposition and precipitation rates, impurity solubility, and snow melting (Flanner et al., 2007; Bond et al., 2013). Previous studies had shown that $\mathrm{BC}$ absorption is underestimated in GEOS-Chem, and this was partly related to the uncertainties in both anthropogenic and biomass burning emission inventories (Wang et al., 2014; Jo et al., 2016; Tuccella et al., 2020). Data analysis and modeling revealed that current inventories underestimate the emissions from shipping and petroleum extraction in the Arctic (Tuccella et al., 2017; Law et al., 2017). On the other hand, dust emission is also uncertain. As an example, Kok et al. (2017) reported a range of values within 1000-2700 $\mathrm{Tg} \mathrm{yr}^{-1}$ for global $\mathrm{PM}_{10}$ dust based on observational constraints. Furthermore, another uncertainty factor that affects our simulations is associated with the fraction of POA emission we assumed as $\mathrm{BrC}$. In order to evaluate the impact of all these uncertainties in snow RF calculation, we perturbed the RAA mixing ratios in snowpack by doubling (BCE-H) and halving (BCE-L) the BCE.

The last two experiments were performed to test the sensitivity of RAA-snow RF to $R_{\mathrm{e}}$ and SCF. As explained in Sect. 2.2, we have estimated $R_{\mathrm{e}}$ with a rough method starting from the broadband snow albedo derived from MERRA2 data. In order to explore the impact of uncertainties in RAAsnow RF related to $R_{\mathrm{e}}$ estimation, we multiplied $\left(R_{\mathrm{e}}-\mathrm{H}\right)$ and divided $\left(R_{\mathrm{e}}-\mathrm{L}\right)$ the snow grain radius by a factor of 2 .

$\mathrm{SCF}$ controls the area where RAA-snow RF acts. In models, SCF is usually calculated using the snow depth (Flanner et al., 2007; Bond et al., 2013). According to Flanner et al. (2007), SCF may differ up to a factor of 2 among the various parameterizations, resulting in an uncertainty of $-17 \% /+8 \%$ in BC-snow RF (Bond et al., 2013). In MERRA2, SCF fraction is parameterized as a function of the snow water equivalent (SWE) (Rienecker et al., 2011). In order to evaluate how SCF uncertainty impacts the RAA-snow RF, SWE has been multiplied (SCF-L) and divided (SCF-H) by a factor of 1.5 .

\subsection{Radiative transfer model}

RAA-snow RF due to snow albedo reduction was calculated with the Rapid Radiative Transfer Model for General Circulation Models (RRTMG) (Iacono et al., 2008). The RRTMG was interfaced with GEOS-Chem output and MERRA2 data as described by Jo et al. (2016) and Tuccella et al. (2020). Aerosol optical properties used for the atmospheric radiative transfer were calculated using the post-processing tool FlexAOD (Curci et al., 2015, 2019).

\section{Results and discussion}

\subsection{Model evaluation}

$\mathrm{BC}$ and BCE mixing ratios in snow diagnosed from GEOSChem deposition fields have been compared with the worldwide observations reported in different works. For the Arctic and North America, we used the data from Doherty et al. (2010, 2014). For China, we inferred the measurements from Ye et al. (2012) and Wang et al. (2013), while for the Himalaya and the Tibetan Plateau the observations were taken from Kopacz et al. (2011). Data for Antarctica were provided from Grenfell et al. (1994), Chylek et al. (1987), Warren and Clarke (1990), and Zatko and Warren (2015).

In Fig. 1, the scatterplot obtained from the comparison between observed and simulated $\mathrm{BC}$ mixing ratios in snow surface layer is reported. In addition, results from the comparison are summarized in Table S2. Model simulations were compared to the observed regional median and standard deviation, provided in the reference papers. Where this information was not available, the analysis was carried out by considering the observed regional mean, together with the minimum and maximum values measured in the region of interest. When measurements corresponded to a specific period falling within the time interval of our simulations (2010-2014), we compared the model results for the same time frame. In other cases, the 5-year average over the same months has been used

The $R^{2}$ coefficient between observed and calculated $\mathrm{BC}$ mixing ratios was 0.84 . This result indicates that the regional variability in BC in snow, spanning over 5 orders of magnitudes is reproduced by the model. Most parts of modeled values $(80 \%)$ were found to drop within a factor of 2 from the observations. This last outcome reflects the model skill in reproducing both the long-range $\mathrm{BC}$ transport and the impact of local major sources on the regional snow darkening. In general, the median bias of the modeled BC was $-13 \%$.

As for the Arctic, a significant bias was found in Greenland, during summer: in this area, modeled $\mathrm{BC}$ is about 7 times larger than the observed median mixing ratio. As discussed in Doherty et al. (2010), BC concentration in Greenland in summertime is larger in the melting layer (around $10 \mathrm{~cm}$ depth) with respect to the surface as BC is left on the 


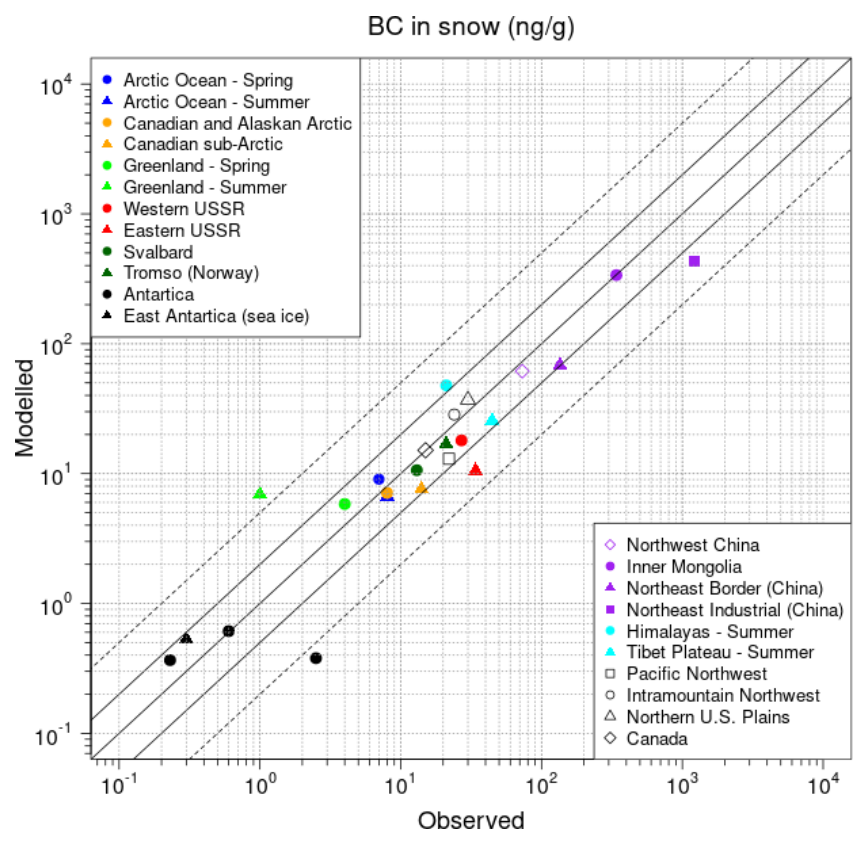

Figure 1. Scatterplots of the observed and modeled BC mixing ratio in the snow. The central continue line is the $1: 1$ line; other continue lines correspond to $1: 2$ and $2: 1$ lines. Dotted lines correspond to $1: 5$ and $5: 1$ lines.

surface by the melted water. Since this process is missing in the calculation schemes, it likely explains the obtained model bias in this case. In eastern Russia, the modeled regional median was underestimated by a factor of 3 . This bias could be related to both measurement uncertainties and model prediction. In fact, in some sites of eastern Russia, BC measurements were affected by local soil dust and assumptions about the Ångström absorption exponent (AAE), which are made for the $\mathrm{BC}$ and non-BC component derivation in snow samples (Doherty et al., 2010). Moreover, some samples were not representative of the regional background because they were affected by local sources from villages (domestic woodburning) and coal-fired power plants (Doherty et al., 2010), which could not be properly resolved by GEOS-Chem given the raw resolution used in this work.

As for Antarctica, the model reproduced the observed BC amount in snowpack and sea ice, except for Simple Dome station, where the mixing ratio is underpredicted by 1 order of magnitude. A similar bias was reported by Flanner et al. (2007), although the authors had used a more advanced scheme to calculate BC content in snow. Moreover, the BC concentration measurement at Simple Dome (Chylek et al., $1987)$ is old (1982-1985) and may not be representative of the present-day Antarctic BC in snow, being much larger than more recent observations $\left(0.20-0.60 \mathrm{ng} \mathrm{g}^{-1}\right)$, as shown in Table 3.

The highest $\mathrm{BC}$ mixing ratios in snow are observed in China: the model reproduced the average magnitude of $\mathrm{BC}$ in snow detected in several regions of the country, with the

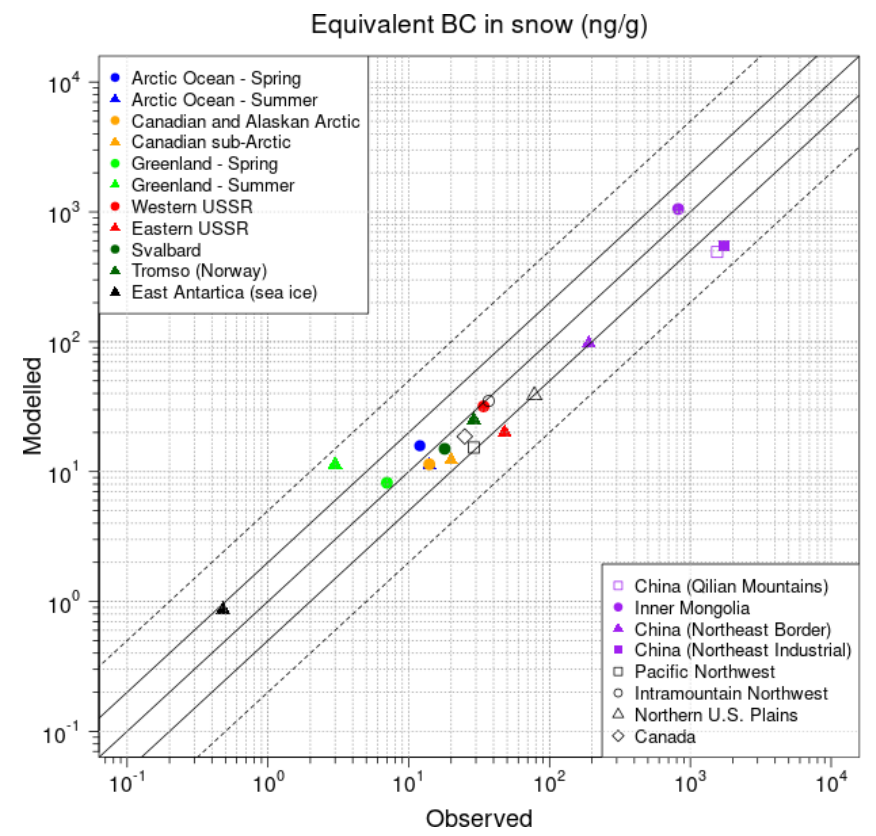

Figure 2. Same as Fig. 1 but for black carbon equivalent (BCE). BCE is defined in Eq. (2) and represents the RAA-snow mass scaled with the MAC of each species.

exception of the industrial Northeast China district. In this region, predicted $\mathrm{BC}$ concentrations are underestimated by a factor of 3 if compared to the typical values in the range of 1000-2000 $\mathrm{ng} \mathrm{g}^{-1}$ in snow surface (Wang et al., 2013). This area, where measurements reported by Wang et al. (2013) were collected (Table 3), hosts the highest number of industrial activities. As a consequence, the model negative bias found for this region may be another effect attributable to the adopted model resolution.

In Fig. 2, the scatterplot resulting from the comparison between observed and simulated BCE (which is defined in Eq. 2) mixing ratios in snow surface layer is shown. Numerical results are also reported in Table 3. The $R^{2}$ coefficient between observed and calculated BCE mixing ratio was 0.60 . As for $\mathrm{BC}, 80 \%$ of the modeled values were within a factor of 2 from the corresponding observations, resulting in a correct simulation of BCE regional variability. The median bias between observed and of modeled BCE was $-21 \%$ : the highest $\mathrm{BCE}$ bias has been found in two regions of China, in particular, BCE is underpredicted by a factor of 3 in the Qilian Mountains and the northeastern industrial region. By contrast, BCE turned out to be overpredicted by a factor of 3-4 in Greenland during the summer months. In this case, the analysis of the light fraction absorption due to non-BC compounds $\left(f_{\text {non-BC }}\right)$ revealed other aspects of the model skill in reproducing the RAAs in snow in terms of biases related to the emissions, transport, and assumptions made for absorbing optical properties. 
Table 3. Global all-sky annual mean surface snow RF $\left(\mathrm{W} \mathrm{m}^{-2}\right)$ of total RAAs, BC, BrC, and mineral dust calculated in the experiments discussed in Sect. 2.4 (see also Table 1). The percentages represent the deviations from the CTRL run.

\begin{tabular}{lrrrr}
\hline Experiment & All RAAs & BC & BrC & Dust \\
\hline CTRL & +0.068 & +0.033 & +0.0066 & +0.012 \\
OSPT & $+0.089(+31 \%)$ & $+0.049(+48 \%)$ & $+0.018(+167 \%)$ & $+0.023(+92 \%)$ \\
BC-H & $+0.073(+8 \%)$ & $+0.038(+16 \%)$ & $+0.0059(-11 \%)$ & $+0.011(-10 \%)$ \\
BC-L & $+0.062(-9 \%)$ & $+0.027(-18 \%)$ & $+0.0073(+10 \%)$ & $+0.013(+5 \%)$ \\
BrC-H & $+0.071(+4 \%)$ & $+0.032(-2 \%)$ & $+0.0095(+44 \%)$ & $+0.012(-)$ \\
BrC-L & $+0.067(-2 \%)$ & $+0.034(+4 \%)$ & $+0.0051(-22 \%)$ & $+0.012(-)$ \\
DUST-H & $+0.071(+5 \%)$ & $+0.032(-4 \%)$ & $+0.0059(-11 \%)$ & $+0.015(+25 \%)$ \\
DUST-L & $+0.063(-7 \%)$ & $+0.035(+5 \%)$ & $+0.0071(+8 \%)$ & $+0.0072(-40 \%)$ \\
BCE-H & $+0.10(+52 \%)$ & $+0.050(+50 \%)$ & $+0.0095(+44 \%)$ & $+0.017(+40 \%)$ \\
BCE-L & $+0.044(-36 \%)$ & $+0.021(-36 \%)$ & $+0.0037(-44 \%)$ & $+0.0078(-35 \%)$ \\
Re-H & $+0.092(+36 \%)$ & $+0.045(+36 \%)$ & $+0.0088(+33 \%)$ & $+0.016(+30 \%)$ \\
Re-L & $+0.050(-27 \%)$ & $+0.024(-27 \%)$ & $+0.0051(-22 \%)$ & $+0.0090(-25 \%)$ \\
SCF-H & $+0.088(+29 \%)$ & $+0.043(+29 \%)$ & $+0.0081(+22 \%)$ & $+0.016(+30 \%)$ \\
SCF-L & $+0.058(-15 \%)$ & $+0.029(-13 \%)$ & $+0.0059(-11 \%)$ & $+0.0096(-20 \%)$ \\
\hline Total uncertainty ${ }^{2}$ & $0.035-0.12$ & $0.017-0.059$ & $0.0028-0.019$ & $0.0044-0.025$ \\
& $-49 \% /+77 \%$ & $-50 \% /+61 \%$ & $-57 \% /+183 \%$ & $-63 \% /+112 \%$ \\
\hline
\end{tabular}

${ }^{1}$ For this experiment, total RAA-snow RF was calculated as the sum of the single species. ${ }^{2}$ The lower and upper bounds were calculated by adding in quadrature the RF from each experiment.

In Fig. 3, a comparison between calculated and observed $f_{\text {non-BC }}$ is proposed, where an $R^{2}$ of 0.44 is reported as well as $90 \%$ of the modeled values being within a factor of 2 from observations. Generally, $f_{\text {non-BC }}$ was underestimated by the model, with a median bias of $-17 \%$. The highest bias has been found for seasonal snow in North America. Furthermore, an underestimation of $f_{\text {non-BC }}$ by a factor of 2 has been found in Intramountain Northwest (Rocky Mountains), the northern US Plains (North Dakota), and Canada. In this case, it should be underlined that most parts of the sites in Intramountain Northwest and the northern US Plains are characterized by thin and patchy snow and, therefore, affected by soil dust emitted by local sources (Doherty et al., 2014). This feature is not resolved by the model due to the raw resolution used. Soil dust particles also contribute to absorption in snowy Canadian sites, implying a long-range transport (Doherty et al., 2014) which is not simulated by GEOS-Chem as some local sources are probably missing in the model.

In Greenland during spring, $f_{\text {non-BC }}$ was underestimated by a factor of 2 . In this period, snow RAAs in this country are usually dominated by biomass burning (Doherty et al., $2010)$; therefore, the $f_{\text {non-BC }}$ bias is likely attributable to the $\mathrm{BrC}$ treatment in the model. Moreover, the simulated underestimation could be associated with the POA emissions from $\mathrm{BB}$ as well as the absorption optical properties assumed to scale aged BB BrC mass in BCE calculation. Finally, in western Russia, the underestimation of $\mathrm{BC}$ resulted in a highly biased $f_{\text {non-BC }}$ (factor of 1.5 ).

In summary, the model evaluation through worldwide observations showed a model skill in reproducing BC and BCE mixing ratios in snow. Obtained biases were mainly linked

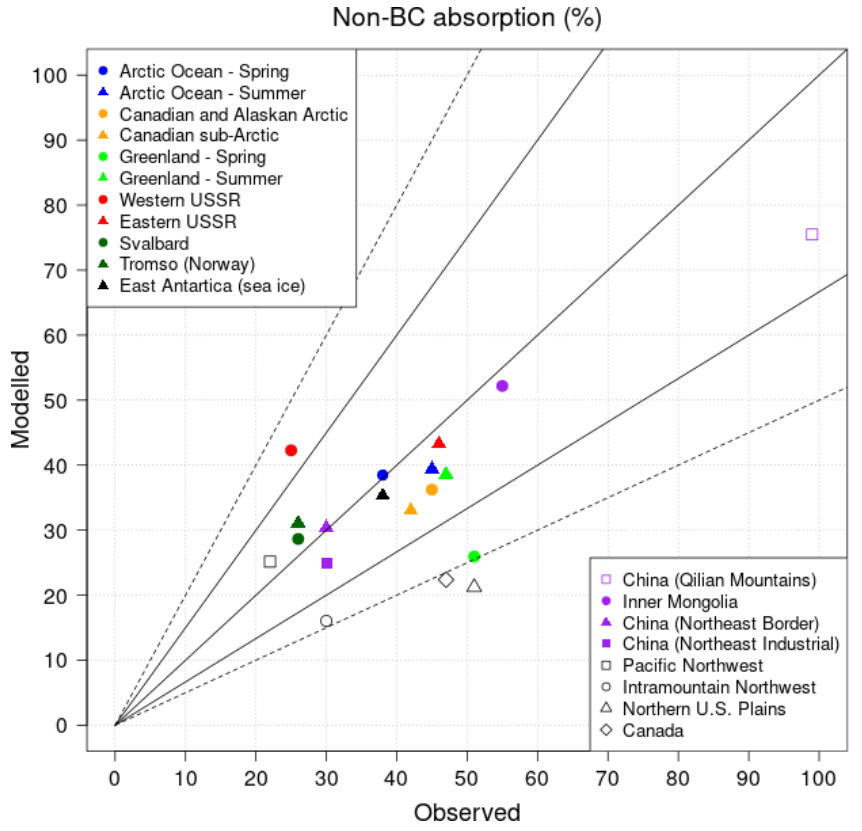

Figure 3. Scatterplots of the observed and modeled $f_{\text {non-BC }}$ in the snow. The central continue line is the $1: 1$ line; other continue lines correspond to $1: 1.5$ and $1.5: 1$ lines. Dotted lines correspond to $1: 2$ and $2: 1$ lines. Non-BC means the sum of $\mathrm{BrC}$ and dust (reported as BC equivalent).

to the emissions of $\mathrm{BC}, \mathrm{POA}$, and dust emissions, while error in $\mathrm{BCE}$ and $f_{\text {non-BC }}$ simulations was likely related to the assumptions about the RAA optical properties. A source of uncertainty in model evaluation could be represented by 
measurement errors. For example, according to Doherty et al. (2010), margins of error in BC and BCE measurements are related to both instrumental errors and assumptions made on the aerosol absorbing optical properties, which results in a total uncertainty estimation up to $\pm 50 \%$.

\subsection{Present-day global radiative forcing}

In Fig. 4, the spatial pattern of the annual surface RF presentday average (2010-2014) from all RAAs, BC, BrC, and dust in snow is shown, as estimated from the CTRL run and in allsky conditions. In the following discussion, anthropogenic RAAs were considered to be particles emitted by FF and BF sources and SOA formed by light photooxidation of aromatic compounds. $\mathrm{BC}$ and $\mathrm{BrC}$ from $\mathrm{BB}$ and biogenic SOA were considered to be natural. Soil dust was also considered to be a natural aerosol, even though about $20 \%-25 \%$ of the total present-day emissions are attributed to human activity (Ginoux et al., 2012); these anthropogenic dust sources were not taken into account in this analysis.

Global-average RF associated with all RAAs was $+0.068 \mathrm{~W} \mathrm{~m}^{-2}$. The largest values were found in northeastern China and the Tibetan Plateau. As expected, global RAA-snow RF was dominated by $\mathrm{BC} \mathrm{RF}$, resulting in $+0.033 \mathrm{~W} \mathrm{~m}^{-2}$. This value is about $18 \%$ lower than the best estimation of $0.040 \mathrm{~W} \mathrm{~m}^{-2}$, reported by Bond et al. (2013). In Fig. S1, RF of BC, divided by source, is shown. About $80 \%\left(+0.025 \mathrm{~W} \mathrm{~m}^{-2}\right)$ of $\mathrm{BC}$-snow RF was due to the anthropogenic sources. FF BC in snow RF acts everywhere, especially in southeastern Canada, eastern Greenland, northeastern China, and the Tibetan Plateau. BF BC showed an impact in eastern Europe, northeastern China, and the Tibetan Plateau. Eventually, BC from biomass burning occurred in Siberia and at high latitudes as a consequence of the boreal fires.

In our model, soil dust is the second light absorber in snow, having an average $\mathrm{RF}$ of $+0.012 \mathrm{~W} \mathrm{~m}^{-2}$, which was about 3 times lower than the radiative forcing due to $\mathrm{BC}$. RF of dust in snow was relevant in the Asian regions, especially downwind of the deserts and the Tibetan Plateau, where values up to $+1.7 \mathrm{~W} \mathrm{~m}^{-2}$ are simulated. In some regions of Kazakhstan, Mongolia, Manchuria, the Tibetan Plateau, Pakistan, and Afghanistan, dust-snow RF is on average 2-3 times larger than what is exerted by BC. In Mongolia, dust RF is up to 4 times larger than $\mathrm{BC}$.

Estimation of snow $\mathrm{RF}$ for $\mathrm{BrC}$ was $+0.0066 \mathrm{~W} \mathrm{~m}^{-2}$, about 5 times lower than what was calculated for BC. Lin et al. (2014) had reported values of $0.0011-0.0031 \mathrm{~W} \mathrm{~m}^{-2}$ for $\mathrm{RF}$ of $\mathrm{BrC}$ in snow as a result of an OA emission change of $60 \mathrm{Tg} \mathrm{yr}^{-1}$ since preindustrial times. Starting from this RF, normalized to the emission change, the present-day RF may be estimated by using the current OA emission $\left(124 \mathrm{Tg} \mathrm{yr}^{-1}\right)$ used in Lin et al. (2014). According to this scaling, the resulting RF was $0.0020-0.0055 \mathrm{~W} \mathrm{~m}^{-2}$; therefore our estimation was above previous upper bounds. In Fig. S2, the snow RF of BrC, divided by source, is displayed. The BF $\mathrm{BrC}$ radiative effect was relevant in northeastern China and the Tibetan Plateau, while $\mathrm{BB} \mathrm{BrC}$ was dominant at high latitudes. Based on our model, $\mathrm{BF}$ and $\mathrm{BB}$ contribution to annual BrC-snow RF was about $38 \%\left(+0.0025 \mathrm{~W} \mathrm{~m}^{-2}\right)$ and $47 \%\left(+0.0031 \mathrm{~W} \mathrm{~m}^{-2}\right)$, respectively. SOA accounts for $15 \%\left(+0.0010 \mathrm{~W} \mathrm{~m}^{-2}\right)$ of $\mathrm{OA}$ absorption, and its effect is limited at high latitudes in late spring and summer.

It should be noted that the sum of BC-, BrC-, and dustsnow RF is lower than the forcing of all RAAs. Albedo reduction does not increase linearly with the addition of RAAs because the light that penetrates in the snowpack decreases as RAA concentration increases (Dang et al., 2017). As a consequence of this non-linearity, it is not straightforward to calculate the relative contribution of each absorbing impurity to total RF. An estimation may be given through the sequential factor separation analysis (Schär and Kröner, 2017); according to this method, non-BC compounds account for about $40 \%$ of the absorption in snow. In addition, we found that carbonaceous aerosols ( $\mathrm{BC}$ and $\mathrm{BrC}$ ) control about $75 \%$ $\left(+0.046 \mathrm{~W} \mathrm{~m}^{-2}\right)$ of snow RF exerted by RAAs. The contribution of anthropogenic emissions to RAA absorption in snow is around $56 \%\left(+0.031 \mathrm{~W} \mathrm{~m}^{-2}\right)$, meaning that slightly less than half of RAA-snow forcing is due to natural sources.

Total RAA-snow RF estimated in this study is about 67 times lower than the direct radiative effect exerted by RAAs $\left(+0.36\right.$ and $+0.10 \mathrm{~W} \mathrm{~m}^{-2}$ for $\mathrm{BC}-\mathrm{BrC}$ mixture and dust, respectively), calculated in our previous study (Tuccella et al., 2020). However, comparing RAA forcings in the atmosphere and in snow by scaling them with their efficacies (Hansen et al., 2005), they are of the same order of magnitude. Forcing efficacy for $\mathrm{BC}$ in snow has been estimated to be 3 times larger than the one resulting from $\mathrm{CO}_{2}$ (Flanner et al., 2007; Bond et al., 2013; Boucher et al., 2013). Assuming that the same efficacy is valid for both $\mathrm{BrC}$ and dust, the effective present-day RF from RAAs in snow obtained in this study is $+0.20 \mathrm{~W} \mathrm{~m}^{-2}$. The atmospheric forcing estimated in Tuccella et al. (2020) may be scaled with the efficacies reported by Hansen et al. (2005), resulting in a total RAA effective forcing near $+0.30 \mathrm{~W} \mathrm{~m}^{-2}$.

\subsection{Present-day regional and seasonal radiative forcing}

In this section, a further investigation on the regional and seasonal dependence of RAA-snow RF is proposed. To this aim, the globe has been divided into five regions, as defined in Table 4. In Fig. 5, RF values from RAAs in snow at the regional scale are represented as a function of season. The same figure also reports the relative contribution of each species to total RF.

In the Arctic, total RAA-snow RF was +0.83 and $+0.59 \mathrm{~W} \mathrm{~m}^{-2}$ in spring and summer, respectively: about $40 \%$ of this forcing was attributable to non-BC compounds. According to our model, $\mathrm{BrC}$ contributed $14 \%$ of the the total absorption in spring and reached the maximum values 
ALL /Snow Surf RF - CTRL - $+0.068 \mathrm{~W} / \mathrm{m}^{2}$
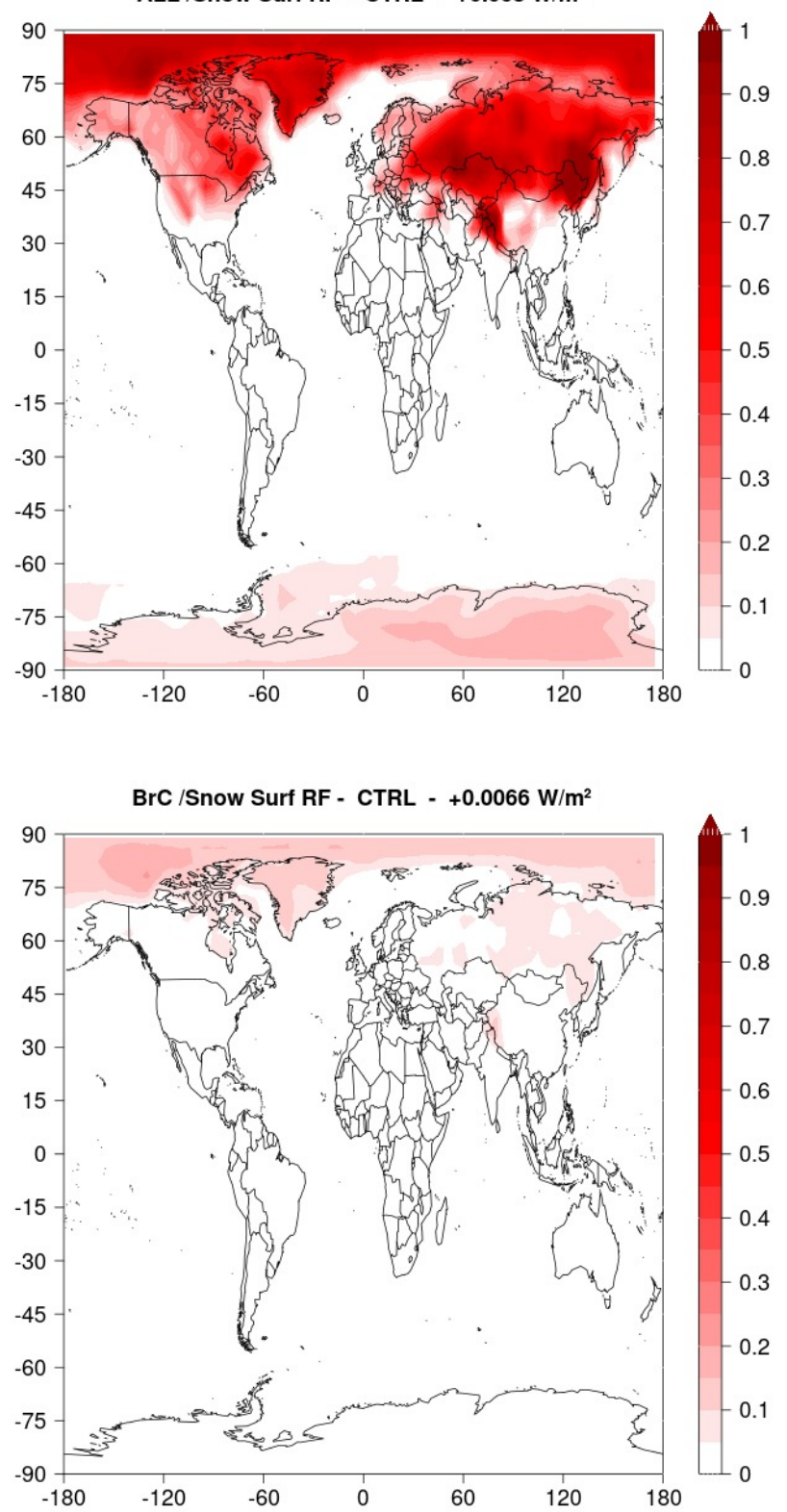

BC /Snow Surf RF - CTRL - $+0.033 \mathrm{~W} / \mathrm{m}^{2}$
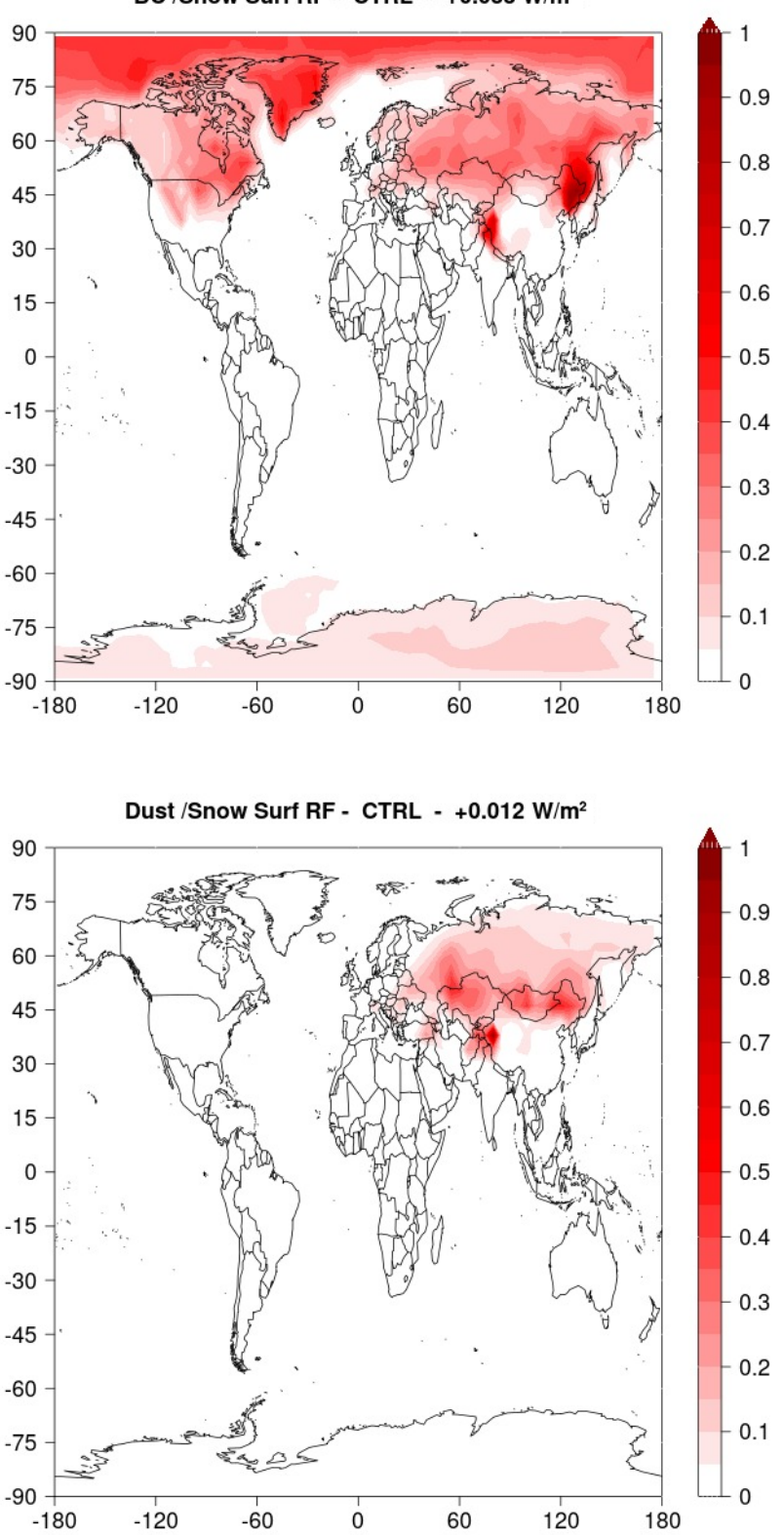

Figure 4. All-sky annual mean (2010-2014) radiation-absorbing aerosols (RAAs), black carbon (BC), brown carbon (BrC), and soil dust in snow radiative forcing $(\mathrm{RF})$ calculated from the CTRL experiment.

Table 4. Domain of the regions used in this study.

\begin{tabular}{lll}
\hline Region & Latitude range & Longitude range \\
\hline Arctic & $60-90^{\circ} \mathrm{N}$ & $-180-180^{\circ} \mathrm{E}$ \\
North America & $29-60^{\circ} \mathrm{N}$ & $-155-60^{\circ} \mathrm{E}$ \\
Europe & $40-60^{\circ} \mathrm{N}$ & $-10-45^{\circ} \mathrm{E}$ \\
Asia & $25-60^{\circ} \mathrm{N}$ & $45-160^{\circ} \mathrm{E}$ \\
Antarctica & $90-60^{\circ} \mathrm{S}$ & $-180-180^{\circ} \mathrm{E}$ \\
\hline
\end{tabular}

$\left(+0.13 \mathrm{~W} \mathrm{~m}^{-2}\right)$ in summer, where $32 \%$ of the overall RAA $\mathrm{RF}$ is concentrated. BrC RF is higher in spring, especially on the snow land of Siberia and at European high latitudes (Figs. S3, S4, S5). This forcing is linked to both BF and $\mathrm{BB}$ sources. During summer, BrC RF is dominated by BB as SOA accounted for about $13 \%\left(+0.017 \mathrm{~W} \mathrm{~m}^{-2}\right)$ of $\mathrm{BrC}$ forcing. By contrast, soil dust-snow RF has been found to be at a maximum in spring $\left(+0.12 \mathrm{~W} \mathrm{~m}^{-2}\right)$, accounting for $24 \%$ of the total forcing, whilst its radiative impact in snow is negligible in summer. Dust RF in the Arctic is limited to the spring months during the Arctic haze transport period, 

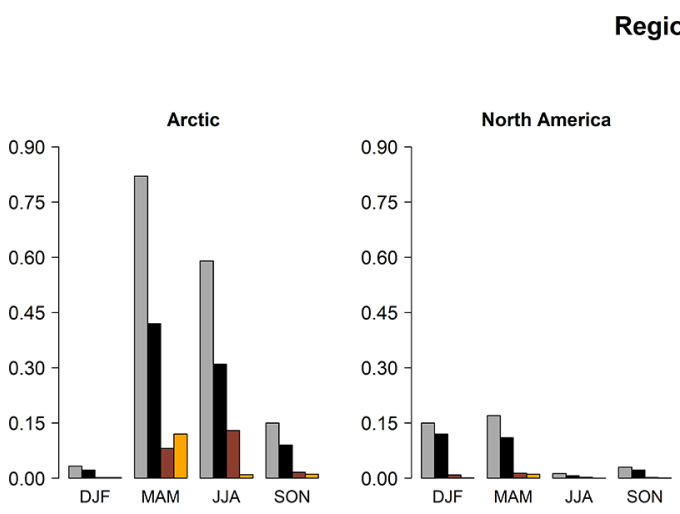

Regional and seasonal RAA snow RF (W/m²)
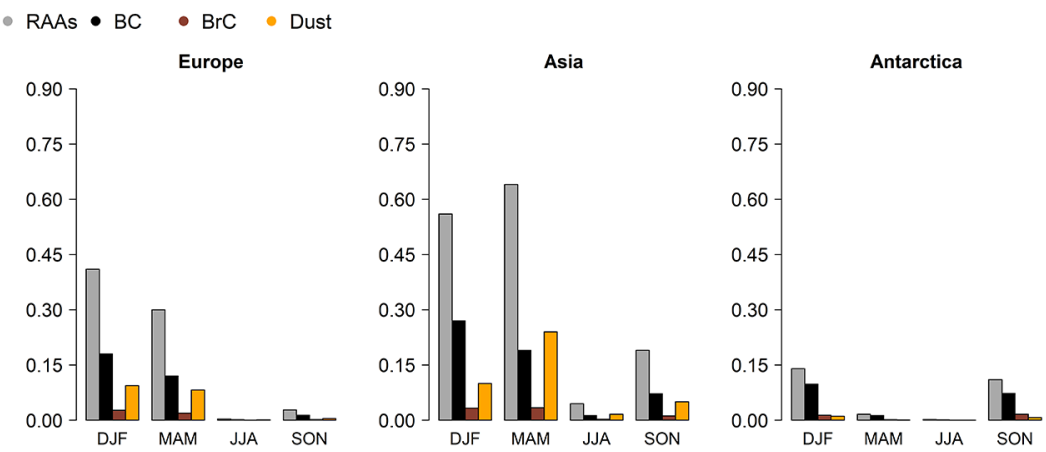

Contribution (\%)
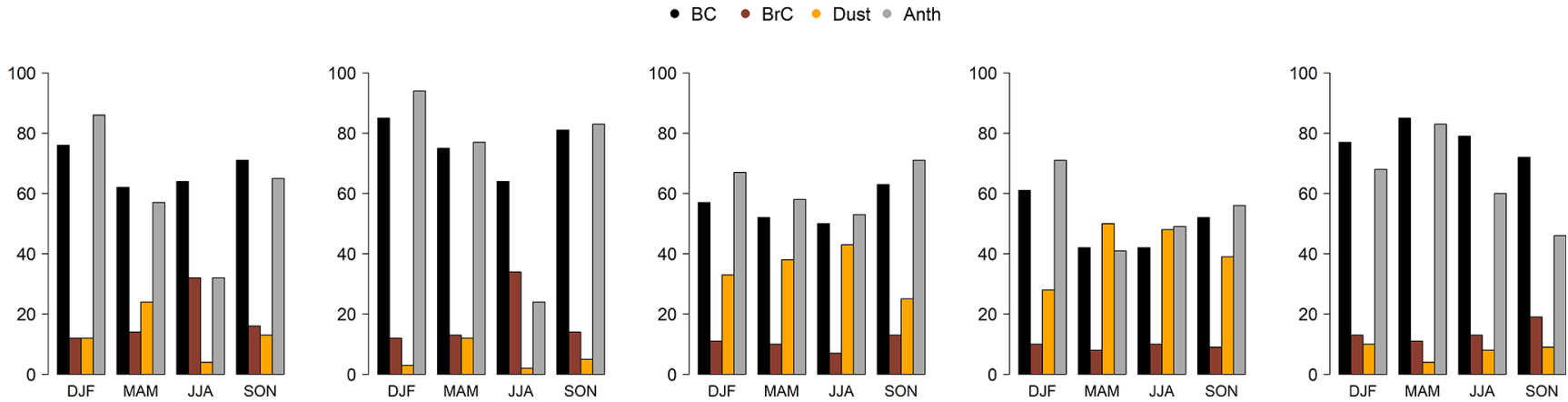

Figure 5. Top panel: all-sky regional and seasonal averages (2010-2014) of total RAA-, black carbon (BC)-, brown carbon (BrC)-, and soil dust-snow radiative forcing (RF), calculated from the CTRL experiment in the Arctic, North America, Europe, Asia, and Antarctica. Bottom panel: contribution of each single species and anthropogenic RAAs to total forcing. The anthropogenic contribution is given by $\mathrm{BC}$ and BrC from fossil fuel (FF) and biofuel (BF) sources and aromatic SOA.

reflecting the absence of significant sources at high latitudes. Arctic dust absorption in springtime is important in Siberia, while a minor impact was found in North America and sea ice (Fig. S6). Moreover, about $60 \%$ of RAA-snow RF in the Arctic was attributable to anthropogenic sources in spring. In summer, the anthropogenic contribution dropped to $30 \%$ as $\mathrm{RF}$ is dominated by BB. In fall, the calculated RAA-snow radiative effect was $+0.15 \mathrm{~W} \mathrm{~m}^{-2}, 30 \%$ of this forcing being due to non-BC aerosols, while $65 \%$ is determined by anthropogenic sources.

The lowest values of RAA-snow RF in the middle latitudes were found in North America, where the total RAA forcing resulted in 0.15 and $0.17 \mathrm{~W} \mathrm{~m}^{-2}$ in winter and spring, respectively. In North America, non-BC-particle snow RF was the lowest obtained in our regional analysis. $\mathrm{BrC}$ and dust RFs showed a peak occurrence in spring, constituting $13 \%\left(+0.014 \mathrm{~W} \mathrm{~m}^{-2}\right)$ and $12 \%\left(+0.011 \mathrm{~W} \mathrm{~m}^{-2}\right)$ of the total forcing, respectively. RAA forcing was dominated by anthropogenic sources, $94 \%$ in winter and $77 \%$ in spring; nevertheless, non-BC forcing is likely underestimated. As discussed in Sect. 3.2, our model underestimated $f_{\text {non-BC }}$ by about a factor of 2 in North American mountain regions as local dust sources are missed in the model. As a consequence, dust forcing could be larger than the estimations we reported in our analysis. Doubling BCE attributed to dust in North America, the corresponding RF increased by about $80 \%$. Anthropogenic sources contributed $94 \%$ and $77 \%$ of the RAA forcing in winter and spring, respectively. However, anthropogenic impact should be reduced by increasing dust contribution to the forcing.

On the European continent, total RAA RF was +0.41 and $+0.30 \mathrm{~W} \mathrm{~m}^{-2}$ in winter and spring, respectively. BC absorption represented slightly more than half of the total forcing. $\mathrm{BrC}$ forcing was dominated by $\mathrm{BF}$ and located in eastern regions over Europe (Fig. S4). Absorbing OA contributed about $10 \%$ of the total forcing $\left(+0.027 \mathrm{~W} \mathrm{~m}^{-2}\right.$ in winter and $+0.019 \mathrm{~W} \mathrm{~m}^{-2}$ in spring). The largest non-BC-compound forcing was caused by soil dust. The radiative impact of dust was relevant in eastern Europe and European Alp snowpack, where the dust-snow RF was about $30 \%-40 \%$ of the total $\left(+0.027\right.$ and $+0.019 \mathrm{~W} \mathrm{~m}^{-2}$ in winter and spring, respectively). Anthropogenic sources explained $67 \%$ of European RAA-snow RF in winter: its contribution dropped to $58 \%$ in spring due to a larger influence of dust.

The largest RAA-snow RF values in the middle latitudes were found in Asia. In this area, RAA RF values were +0.56 
and $+0.64 \mathrm{~W} \mathrm{~m}^{-2}$ in winter and spring, respectively. $\mathrm{BrC}$ contribution was constant $\left(10 \%\right.$, about $\left.+0.033 \mathrm{~W} \mathrm{~m}^{-2}\right)$ between December and May. In particular, BF sources impacted the snow of northeastern China, Kazakhstan, southern Russia, and High Mountain Asia, while BB determined some impact in southern Siberia (Fig. S4). Soil dust played a key role in Asia. According to our model, dust-snow forcing was +0.10 and $+0.24 \mathrm{~W} \mathrm{~m}^{-2}$ in winter and spring, respectively. Spring dust forcing was larger than $\mathrm{BC}\left(+0.19 \mathrm{~W} \mathrm{~m}^{-2}\right)$ found in the same regions and constituted about a half of the total forcing. As a result, non-BC compounds gave the largest contribution (+60\%) to RAA-snow RF in Asia during spring. Dust particles caused the anthropogenic source contribution to all RAA forcing to drop from $71 \%$ in winter, to $41 \%$ in springtime. Moreover, it should be noted that Asiatic RAA-snow spatio-temporally averaged forcing was low in summer $\left(+0.045 \mathrm{~W} \mathrm{~m}^{-2}\right)$, with relevant values in the High Mountain Asia region, where it was up to $3 \mathrm{~W} \mathrm{~m}^{-2}$. About $60 \%$ of this forcing was due to non-BC compounds, while $10 \%$ and $50 \%$ is produced by $\mathrm{BrC}$ and dust, respectively. The middle latitudes of Asia are the only regions where the snow RAAs are relevant in fall. In fall, total RAA forcing was $+0.19 \mathrm{~W} \mathrm{~m}^{-2}$, and about half of this radiative effect is attributable non-BC compounds (10\% and $40 \%$ to $\mathrm{BrC}$ and dust, respectively).

According to our model, the lowest RAA-snow radiative effect has been calculated in Antarctica. Here, the highest $\mathrm{RF}$ values have been found in winter and fall (austral summer and spring) as they were +0.14 and $+0.11 \mathrm{~W} \mathrm{~m}^{-2}$, respectively. The contribution of non-BC compounds was estimated to be $20 \%-30 \%(10 \%-20 \%$ is due to $\mathrm{BrC}$, and $10 \%$ is from dust), while anthropogenic sources impacted $68 \%$ and $46 \%$ in winter and fall, respectively. The role of soil dust in Antarctica snow darkening could be underestimated in this study as dust emission from arid regions of the Southern Hemisphere calculated by our model was $65 \mathrm{Tg} \mathrm{yr}^{-1}$. For the same hemisphere, Ginoux et al. (2012) calculated an emission of $142 \mathrm{Tg} \mathrm{yr}^{-1}$, half of which is linked to anthropogenic sources. This means that dust emission in the austral hemisphere was underestimated in our simulations by a factor of 2 due to the missing dust anthropogenic sources. As a result, the presence of anthropogenic dust in the model could have increased its role in Antarctica RAA-snow RF and reduced the impact of anthropogenic compounds. Moreover, as discussed in Sect. 3.1, observations used to evaluate predicted RAA concentration in snow are obsolete and may not be representative of the current black carbon level in the Antarctica snow (see Table 3). The most recent measurements of BC, BCE, and non-BC were carried out in 2012 (Zatko and Warren, 2015) and are relative to sea ice of East Antarctica. Although our modeled RAAs in snow are in agreement with these observations, this does not imply the same in other regions of Antarctica. As a consequence, it is difficult to establish the level of uncertainty in RF associated with the snow RAA concentration calculation.

\subsection{Discussion of uncertainties}

In this section, the impact of RAAs in snow uncertainties on the RF is addressed. The impact of each single uncertainty was evaluated by comparing the perturbed experiments with the CTRL simulation. The results are summarized in Table 3.

First, uncertainty in $\mathrm{BC}, \mathrm{BrC}$, and dust due to the presence of multiple radiation-absorbing impurities in the snowpack has been assessed. An increasing radiative effect, with respect to CTRL, was found when RF is calculated for one species at a time (OSPT). According to our model, BC-snow $\mathrm{RF}$ increased by $48 \%$ when $\mathrm{BrC}$ and dust are not present in the snow. This result is above the upper bound of $10 \%-40 \%$, estimated in previous studies (Flanner et al., 2009; Bond et al., 2013), where only the role of dust was considered in modulating the BC-snow RF. BrC forcing was enhanced by $167 \%$ when black carbon and dust are in the snowpack. This value is in line with Beres et al. (2020), where a reduction in local $\mathrm{BrC} \mathrm{RF}$ of about a factor of 2 is reported, when the species is added to a dark snowpack. Finally, dust RF increased by $92 \%$ in the OSPT simulation.

Uncertainty associated with the MAC of BC was $-18 \%$ and $+16 \%$ when an $E_{\mathrm{abs}}=1.1(\mathrm{BC}-\mathrm{L})$ and $E_{\mathrm{abs}}=1.9(\mathrm{BC}-$ $\mathrm{H})$ are applied to the aged coated particles. The estimated range is comparable with those provided by previous works, where $\mathrm{BC}$ forcing uncertainty due to assumptions of its optical properties was estimated in the range $\pm 12 \%$ (Bond et al., 2013). BrC forcing increased by $44 \%$ when the blanching of aged $\mathrm{BB}$ is missed $(\mathrm{BrC}-\mathrm{H})$. Taking into account a whitening process for $\mathrm{BF}$ (BrC-L), BrC-snow $\mathrm{RF}$ is lowered by $22 \%$. The uncertainty in soil dust RF associated with the refractive index was $-40 \%$ and $+25 \%$ for DUST-L and DUST-H simulations, respectively.

Uncertainties in absorbing optical properties of a given species may also affect the forcing of other RAAs deposited on the snowpack. When $\mathrm{BC}$ absorption was increased in the $\mathrm{BC}-\mathrm{H}$ experiment, $\mathrm{BrC}$ and dust forcing was reduced by about $10 \%$. Similarly, in the BC-L simulation, the forcing of $\mathrm{BrC}$ and dust increased by $10 \%$ and $5 \%$, respectively. Uncertainty in $\mathrm{BrC}$ absorption properties had a negligible effect (less than 5\%) on BC- and the dust-snow radiative effect. By contrast, the perturbation to soil dust absorption optical properties (DUST-H and DUST-L) affected BrC-snow RF by about $10 \%$; however, the effect on $\mathrm{BC}$ forcing was negligible. The estimated overall uncertainties in RF associated with the absorbing optical properties of RAAs in snow were $-18 \% /+17 \%,-27 \% /+45 \%,-41 \% /+25 \%$, and $-12 \% /+10 \%$ for BC-, BrC-, soil dust-, and total RAAsnow RF.

Uncertainties related to RAA mixing ratio in snow obtained by halving (BCE-L) and doubling (BCE-H) the BCE were $-36 \% /+50 \%,-44 \% /+44 \%$, and $-35 \% /+40 \%$ for $\mathrm{BC}, \mathrm{BrC}$, and mineral dust, respectively. The uncertainty in total RAA-snow forcing due to BCE was $-36 \% /+52 \%$. 
As for uncertainties linked to $R_{\mathrm{e}}$ (snow aging), we found ranges of $30 \%-36 \%$ for $R_{\mathrm{e}}-\mathrm{H}$ and $22 \%-27 \%$ for $R_{\mathrm{e}}-\mathrm{L}$. RAA-snow RF changes due to SCF perturbation were in the range of $22 \%-30 \%$ and $11 \%-20 \%$ for $\mathrm{SCF}-\mathrm{H}$ and SCF-L, respectively. The overall uncertainties in RF due to snowpack properties were $-19 \% /+30 \%,-25 \% /+40 \%$, $-32 \% /+30 \%$, and $-31 \% /+46 \%$ for $\mathrm{BC}, \mathrm{BrC}$, dust, and total RAAs.

In summary, the estimated overall uncertainty in RF was $-49 \% /+77 \%\left(0.035-0.12 \mathrm{~W} \mathrm{~m}^{-2}\right),-50 \% /+61 \%(0.017-$ $\left.0.059 \mathrm{~W} \mathrm{~m}^{-2}\right),-57 \% /+183 \%\left(0.0028-0.019 \mathrm{~W} \mathrm{~m}^{-2}\right)$, and $-63 \% /+122 \%\left(0.0044-0.025 \mathrm{~W} \mathrm{~m}^{-2}\right)$ for total RAAs, BC, $\mathrm{BrC}$, and dust, respectively. The total uncertainties were calculated as the root sum of single squared errors, assuming that the single uncertainties are independent. Our results indicate that the lower bounds of total uncertainty in $\mathrm{BC}, \mathrm{BrC}$, and dust were comparable. By contrast, upper bounds for $\mathrm{BrC}$ and dust were about 2 and 3 times larger than the one of BC. According to our calculation, this uncertainty was related to the simultaneous presence of multiple RAA species in the snowpack (OSPT experiment).

Furthermore, it has to be highlighted that RAA-snow RF can be affected by other uncertainties than what is assessed in our study. In particular, the cloud cover, which affects the incident solar radiation at the surface and RAA optical properties in snow, also depends on the microlocation of impurities (i.e., if the aerosol particles are externally or internally mixed with snow grains). In the second case, some authors estimated a BC absorption about 1.4-2.1 times larger with respect to the external mixing (Hansen and Nazarenko, 2004; Flanner et al., 2012; He et al., 2014). Another uncertainty is related to the snow grain shape: non-spherical grain assumption reduces the BC-snow RF by $20 \%-40 \%$ relative to spherical snow grains (He et al., 2014).

\section{Conclusions}

We presented a global modeling study to assess the presentday $\mathrm{RF}$ in snow due to the most relevant radiation-absorbing aerosols (BC, BrC, and dust). While BC RF in snow has been extensively studied (e.g., Bond et al., 2013; Boucher et al., 2013), the forcing from $\mathrm{BrC}$ and dust and associated uncertainties were not assessed in IPCC AR5. According to the IPCC Special Report on the Ocean and Cryosphere in a Changing Climate, there is low and medium confidence in the attribution of $\mathrm{RF}$ of $\mathrm{BrC}$ and dust in snow, respectively. Moreover, given that the snow albedo change is not linear with the impurity content (Flanner et al., 2009; Dang et al., 2017), RF from RAAs in snow has to be calculated simultaneously taking into account the concentrations of $\mathrm{BC}, \mathrm{BrC}$, and mineral soil dust.

Herein, we used the GEOS-Chem global chemistry and transport model to simulate $\mathrm{BC}, \mathrm{BrC}$, and dust deposition on the snowpack. The present-day radiative RF due to RAAs in snow was calculated considering the simultaneous presence in the snow of $\mathrm{BC}, \mathrm{BrC}$, and dust. $\mathrm{BC}$ and black carbon equivalent (BCE) mixing ratios in snow were calculated starting from simulated deposition fields and precipitation fluxes. The obtained BC and BCE concentrations in the snowpack have been validated through worldwide observations. The model was able to reproduce the observed regional variations with an $R^{2}$ of 0.84 and 0.60 for $\mathrm{BC}$ and $\mathrm{BCE}$, respectively. A total of $80 \%$ of the modeled BC and BCE values were within a factor of 2 from the observations. The median bias for the same quantities was $-13 \%$ and $-21 \%$. The model also reproduced the range of observed $f_{\text {non-BC }}$ with an $R^{2}$ of 0.44 and a median bias of $-17 \%$.

According to the model, global-annual-mean presentday RAA-snow RF at the surface was $+0.037,+0.0064$, +0.013 , and $+0.068 \mathrm{~W} \mathrm{~m}^{-2}$ for $\mathrm{BC}, \mathrm{BrC}$, dust, and total RAAs, respectively. Non-BC compounds accounted for $40 \%\left(+0.046 \mathrm{~W} \mathrm{~m}^{-2}\right)$ of RAA-snow global RF, and anthropogenic RAAs contributed $56 \%\left(+0.031 \mathrm{~W} \mathrm{~m}^{-2}\right)$ of the forcing.

At a regional scale, RF exhibited large variability in terms of intensity and species apportionment. The largest total RAA-snow RF was found in the Arctic during spring $\left(+0.83 \mathrm{~W} \mathrm{~m}^{-2}\right)$ and summer $\left(+0.59 \mathrm{~W} \mathrm{~m}^{-2}\right)$, and $40 \%$ of this forcing was due to non-BC compounds. In particular, non-BC spring $\mathrm{RF}$ is mainly due to the dust $\left(+0.12 \mathrm{~W} \mathrm{~m}^{-2}\right)$, while non-BC was driven by $\mathrm{BB} \operatorname{BrC}\left(+0.13 \mathrm{~W} \mathrm{~m}^{-2}\right)$ in summer. In the middle latitudes, the most relevant RAA-snow forcing was obtained in Asia, with +0.56 and $+0.64 \mathrm{~W} \mathrm{~m}^{-2}$ in winter and spring, respectively. The $\mathrm{BrC}$ contribution was constant during winter and spring $(10 \%$, about $+0.033 \mathrm{~W} \mathrm{~m}^{-2}$ ), while soil dust played a key role in forcing over Asia: its radiative effect $\left(+0.24 \mathrm{~W} \mathrm{~m}^{-2}\right)$ was larger than the one of $\mathrm{BC}$ and represented $50 \%$ of the total RAA RF in spring. RAA forcing in the High Mountain Asia region was up to $3 \mathrm{~W} \mathrm{~m}^{-2}$ in summertime, and $60 \%$ of it is attributable to non-BC aerosols. North America exhibited the lowest RAA-snow RF $\left(0.15\right.$ and $0.17 \mathrm{~W} \mathrm{~m}^{-2}$ in winter and spring, respectively) and the lowest non-BC contribution (about $20 \%$ ) in the middle latitudes. As for Europe, total RAA RF was +0.41 and $+0.30 \mathrm{~W} \mathrm{~m}^{-2}$ in winter and spring, respectively. BC contributed slightly more than half of the total forcing. The most relevant non-BC was given by dust (30\%-40\% of the total). In Antarctica, the highest values of RF have been found in winter and fall $(+0.14$ and $+0.11 \mathrm{~W} \mathrm{~m}^{-2}$, respectively), and the contribution of non-BC compounds was estimated to be in the range of $20 \%-30 \%$.

In the Arctic, $60 \%$ of springtime RF was due to anthropogenic sources, while it dropped down to $30 \%$ in summer due to BB. In Asia, anthropogenic compounds contributed $71 \%$ of the total forcing in winter, while the contribution was $41 \%$ in springtime because of the presence of dust. A similar behavior has been found in Europe, while in North America RAA-snow RF was always dominated by anthropogenic emissions. 
Finally, we also explored the sensitivity of RF due to the simultaneous presence of multiple RAAs in snow, absorption optical properties, uncertainties in impurity mixing ratio, snow grain size, and snow coverage. The overall uncertainty in RF associated with these factors was $-49 \% /+77 \%$ $\left(0.035-0.12 \mathrm{~W} \mathrm{~m}^{-2}\right),-50 \% /+61 \%\left(0.017-0.059 \mathrm{~W} \mathrm{~m}^{-2}\right)$, $-57 \% /+183 \%\left(0.0028-0.019 \mathrm{~W} \mathrm{~m}^{-2}\right)$, and $-63 \% /+122 \%$ $\left(0.0044-0.025 \mathrm{~W} \mathrm{~m}^{-2}\right)$ for total RAAs, BC, BrC, and dust, respectively. These results highlight that uncertainty upper bounds of $\mathrm{BrC}$ and dust were about 2 and 3 times larger than the one of BC. This uncertainty was mainly due to the simultaneous presence of multiple absorbing impurities in the snow. Therefore, we may conclude that RAA-snow RF is very sensitive to the concomitant presence of more species, especially for non-BC compounds, given their minor absorption with respect to $\mathrm{BC}$.
Efficacy of RF associated with $\mathrm{BC}$ in snow was 3 times larger than forcing from $\mathrm{CO}_{2}$ (Flanner et al., 2007; Bond et al., 2013; Boucher et al., 2013). Assuming the same efficacy for BrC and dust, effective RF exerted by RAAs in snow found in this study was $+0.20 \mathrm{~W} \mathrm{~m}^{-2}$, a value comparable with the RAA effective atmospheric forcing (about $+0.30 \mathrm{~W} \mathrm{~m}^{-2}$ ) obtained from Tuccella et al. (2020). Given that RF of RAAs in snow acts mainly on the cryosphere, it may potentially have important effects in response to the snow albedo feedback. As a consequence, a reduction in the uncertainties is desirable. According to our results, a first step to reduce uncertainties in RAA-snow RF should be an improvement of the representation of RAAs in snow within models through constraint with local and satellite observations and a better characterization of the emission inventories in current atmospheric models. 
Appendix A: List of abbreviations and symbols

$\begin{array}{ll}\text { AAE } & \text { Absorption Ångström exponent } \\ \text { AOD } & \text { Aerosol optical depth } \\ \text { BB } & \text { Biomass burning } \\ \text { BC } & \text { Black carbon } \\ \text { BCE } & \text { Black carbon equivalent } \\ \text { BF } & \text { Biofuel } \\ \text { BrC } & \text { Brown carbon } \\ \text { DEAD } & \text { Dust Entrainment And Deposition } \\ \text { Eabs } & \text { Black carbon absorption enhancement factor } \\ \text { FF } & \text { Fossil fuel } \\ \text { FlexAOD } & \text { Flexible aerosol optical depth } \\ \text { MAC } & \text { Mass absorption coefficient } \\ \text { MERRA2 } & \text { Modern Era Retrospective-analysis for Research and Application version 2 } \\ \text { NIR } & \text { Near-infrared radiation } \\ \text { OA } & \text { Organic aerosol } \\ \text { POA } & \text { Primary organic aerosol } \\ R_{\mathrm{e}} & \text { Snow grain effective radius } \\ \text { RAA } & \text { Radiation-absorbing aerosol } \\ \text { RF } & \text { Radiative forcing } \\ \text { RRTMG } & \text { Rapid Radiative Transfer Model for General Circulation Models } \\ \text { SCF } & \text { Snow cover fraction } \\ \text { SOA } & \text { Secondary organic aerosol } \\ \text { VIS } & \text { Visible radiation }\end{array}$


Code and data availability. GEOS-Chem simulations used in this study are accessible at https://doi.org/10.17605/OSF.IO/XNTR8 (Tuccella, 2020). Snow impurity measurements are available in the paper referenced in the text. The FlexAOD postprocessing tool can be provided upon request to gabriele.curci@aquila.infn.it. RRTMG code is available at this link: http://rtweb.aer.com/rrtm_frame.html (last access: 3 May 2021; Iacono et al., 2008).

Supplement. The supplement related to this article is available online at: https://doi.org/10.5194/acp-21-6875-2021-supplement.

Author contributions. PT and GP conceptualized the study. PT developed the methodology; PT, GC, and ER developed the software; PT performed the GEOS-Chem and radiative simulations. PT, VC, and GP performed the formal analysis. PT prepared and wrote the original draft. PT, VC, GP, ER, and GC reviewed the original draft. VC and PT administrated the project. PT, GC, and GP acquired the fund.

Competing interests. The authors declare that they have no conflict of interest.

Acknowledgements. The authors are grateful to the four anonymous reviewers who helped to improve the quality of the initial manuscript.

Financial support. This research has been supported by the AXA Research Fund (grant no. 2016-ENV-PostDoc-University of L'Aquila) postdoctoral grant.

Review statement. This paper was edited by Pedro JimenezGuerrero and reviewed by four anonymous referees.

\section{References}

Alexander, D. T. L., Crozier, P. A., and Anderson, J. R: Brown carbon spheres in East Asian outflow and their optical properties, J. Geophys. Res., 321, 833-836, https://doi.org/10.1126/science.1155296, 2008.

Andreae, M. O. and Gelencsér, A.: Black carbon or brown carbon? The nature of light-absorbing carbonaceous aerosols, Atmos. Chem. Phys., 6, 3131-3148, https://doi.org/10.5194/acp-63131-2006, 2006.

Arola, A., Schuster, G., Myhre, G., Kazadzis, S., Dey, S., and Tripathi, S. N.: Inferring absorbing organic carbon content from AERONET data, Atmos. Chem. Phys., 11, 215-225, https://doi.org/10.5194/acp-11-215-2011, 2011.

Beres, N. D., Sengupta, D., Samburova, V., Khlystov, A. Y., and Moosmüller, H.: Deposition of brown carbon onto snow: changes in snow optical and radiative properties, Atmos. Chem. Phys., 20, 6095-6114, https://doi.org/10.5194/acp-20-6095-2020, 2020.
Bey, I., Jacob, D. J., Yantosca, R. M., Logan, J. A., Field, B., Fiore, A. M., Li, Q., Liu, H., Mickley, L. J., and Schultz, M.: Global modeling of tropospheric chemistry with assimilated meteorology: Model description and evaluation, J. Geophys. Res., 106, 23073-23095, https://doi.org/10.1029/2001JD000807, 2001.

Bond, T. C. and Bergstrom, R. W.: Light absorption by carbonaceous particles: an investigative review, Aerosol. Sci. Tech., 40, 27-67, https://doi.org/10.1080/02786820500421521, 2006.

Bond, T. C., Doherty, S. J., Fahey, D. W., Forster, P. M., Berntsen, T., DeAngelo, B. J., Flanner, M. G., Ghan, S., Kärcher, B., Koch, D., Kinne, S., Kondo, Y., Quinn, P. K., Sarofim, M. C., Schultz, M. G., Schulz, M., Venkataraman, C., Zhang, H., Zhang, S., Bellouin, N., Guttikunda, S. K., Hopke, P. K., Jacobson, M. Z., Kaiser, J. W., Klimont, Z., Lohmann, U., Schwarz, J. P., Shindell, D., Storelvmo, T., Warren, S. G., and Zender, C. S.: Bounding the role of black carbon in the climate system: A scientific assessment, J. Geophys. Res.-Atmos., 118, 5380-5552, https://doi.org/10.1002/jgrd.50171, 2013.

Bones, D. L., Henricksen, D. K., Mang, S. A., Gonsior, M., Bateman, A. P., Nguyen, T. B., Cooper, W. J., and Nizkorodov, S. A.: Appearance of strong absorbers and fluorophores in limonene$\mathrm{O}_{3}$ secondary organic aerosol due to $\mathrm{NH}_{4}^{+}$mediated chemical aging over long time scales, J. Geophys. Res., 115, D05203, https://doi.org/10.1029/2009JD012864, 2010.

Boucher, O., Randall, D., Artaxo, P., Bretherton, C., Feingold, G., Forster, P., Kerminen, V.-M., Kondo, Y., Liao, H., Lohmann, U., Rasch, P., Satheesh, S. K., Sherwood, S., Stevens, B., and Zhang, X. Y.: Clouds and Aerosols, in: Climate Change 2013: The Physical Science Basis. Contribution of Working Group I to the Fifth Assessment Report of the Intergovernmental Panel on Climate Change, edited by: Stocker, T. F., Qin, D., Plattner, G.-K., Tignor, M., Allen, S. K., Boschung, J., Nauels, A., Xia, Y., Bex, V., and Midgley, P. M., Cambridge University Press, Cambridge, United Kingdom and New York, NY, USA, 2013.

Brown, H., Liu, X., Feng, Y., Jiang, Y., Wu, M., Lu, Z., Wu, C., Murphy, S., and Pokhrel, R.: Radiative effect and climate impacts of brown carbon with the Community Atmosphere Model (CAM5), Atmos. Chem. Phys., 18, 17745-17768, https://doi.org/10.5194/acp-18-17745-2018, 2018.

Cappa, C. D., Onasch, T. B., Massoli, P., Worsnop, D. R., Bates, T. S., Cross, E. S., Davidovits, P., Hakala, J., Hayden, K. L., Jobson, B. T., Kolesar, K. R., Lack, D. A., Lerner, B. M., Li, S.-M., Mellon, D., Nuaaman, I., Olfert, J. S., Petäjä, T., Quinn, P. K., Song, C., Subramanian, R., Williams, E. J., and Zaveri, R. A.: Radiative Absorption Enhancements Due to the Mixing State of Atmospheric Black Carbon, Science, 337, 1078-1081, https://doi.org/10.1126/science.1223447, 2012.

Chen, Y. and Bond, T. C.: Light absorption by organic carbon from wood combustion, Atmos. Chem. Phys., 10, 1773-1787, https://doi.org/10.5194/acp-10-1773-2010, 2010.

Choobari, O. A., Zawar-Reza, P., and Sturman, A.: The global distribution of mineral dust and its impact on the climate system: a review, Atmos. Res., 138, 152-165, https://doi.org/10.1016/j.atmosres.2013.11.007, 2013.

Chylek, P., Srivastava, V., Cahenzli, L., Pinnik, R. G., Dod, R. L., and Novakov, T.: Aerosol and graphitic carbon content of snow, J. Geophys. Res., 92D8, 9801-19809, https://doi.org/10.1029/JD092iD08p09801, 1987. 
Coppola, E., Verdecchia, M., Giorgi, F., Colaiuda, V., Tomassetti, B., and Lombardi, A.: Changing hydrological conditions in the Po basin under global warming, Sci. Total Environ., 493, 11831196, https://doi.org/10.1016/j.scitotenv.2014.03.003, 2014.

Curci, G., Hogrefe, C., Bianconi, R., Im, U., Balzarini, A., Baro, R., Brunner, D., Forkel, R., Giordano, L., Hirtl, M., Honzak, L., Jimenez-Guerrero, P., Knote, C., Langer, M., Makar, P. A., Pirovano, G., Perez, J. L., San Jose, R., Syrakov, D., Tuccella, P., Werhahn, J., Wolke, R., Zabkar, R., Zhang, J., and Galmarini, S.: Uncertainties of simulated aerosol optical properties induced by assumptions on aerosol physical and chemical properties: an AQMEII-2 perspective, Atmos. Environ., 115, 541552, https://doi.org/10.1016/j.atmosenv.2014.09.009, 2015.

Curci, G., Alyuz, U., Barò, R., Bianconi, R., Bieser, J., Christensen, J. H., Colette, A., Farrow, A., Francis, X., Jiménez-Guerrero, P., Im, U., Liu, P., Manders, A., Palacios-Peña, L., Prank, M., Pozzoli, L., Sokhi, R., Solazzo, E., Tuccella, P., Unal, A., Vivanco, M. G., Hogrefe, C., and Galmarini, S.: Modelling black carbon absorption of solar radiation: combining external and internal mixing assumptions, Atmos. Chem. Phys., 19, 181-204, https://doi.org/10.5194/acp-19-181-2019, 2019.

Dang, C., Brandt, R. E., and Warren, S. G.: Parameterizations for narrowband and broadband albedo of pure snow and snow containing mineral dust and black carbon, J. Geophys. Res., 102, 5446-5468, https://doi.org/10.1002/2014JD022646, 2015.

Dang, C., Warren, S. G., Fu, Q., Doherty, S. J., Sturm, M., and $\mathrm{Su}, \mathrm{J} .:$ Measurements of light-absorbing particles in snow across the Arctic, North America, and China: Effects on surface albedo, J. Geophys. Res.-Atmos., 122, 10149-10168, https://doi.org/10.1002/2017JD027070, 2017.

Doherty, S. J., Warren, S. G., Grenfell, T. C., Clarke, A. D., and Brandt, R. E.: Light-absorbing impurities in Arctic snow, Atmos. Chem. Phys., 10, 11647-11680, https://doi.org/10.5194/acp-1011647-2010, 2010.

Doherty, S. J., Dang, C., Hegg, D. A., Zhang, R., and Warren, G.: Black carbon and other light-absorbing particles in snow of central North America, J. Geophys. Res., 119, 12807-12831, https://doi.org/10.1002/2014JD022350, 2014.

Flanner, M. G. and Zender, C. S.: Linking snowpack microphysics and albedo evolution, J. Geophys. Res.-Atmos., 111, D12208, https://doi.org/10.1029/2005JD006834, 2006.

Flanner, M. G., Zender, C. S., Randerson, J. T., and Rasch, P. J.: Present-day climate forcing and response from black carbon in snow, J. Geophys. Res., 112, D11202, https://doi.org/10.1029/2006JD008003, 2007.

Flanner, M. G., Zender, C. S., Hess, P. G., Mahowald, N. M., Painter, T. H., Ramanathan, V., and Rasch, P. J.: Springtime warming and reduced snow cover from carbonaceous particles, Atmos. Chem. Phys., 9, 2481-2497, https://doi.org/10.5194/acp9-2481-2009, 2009.

Flanner, M. G., Liu, X., Zhou, C., Penner, J. E., and Jiao, C.: Enhanced solar energy absorption by internally-mixed black carbon in snow grains, Atmos. Chem. Phys., 12, 4699-4721, https://doi.org/10.5194/acp-12-4699-2012, 2012.

Forrister, H., Liu, J., Scheuer, E., Dibb, J., Ziemba, L., Thornhill, K. L., Anderson, B., Diskin, G., Perring, A. E., Schwarz, J. P., Campuzano-Jost, P., Day, D. A., Palm, B. B., Jimenez, J. L., Nenes, A., and Weber, R. J.: Evolution of brown car- bon in wildfire plumes, Geophys. Res. Lett., 42, 4623-4630, https://doi.org/10.1002/2015GL063897, 2015.

Ginoux, P., Prospero, J. M., Gill, T. E., Hsu, N. C., and Zao, M.: Global-scale attribution of anthropogenic and natural dust sources and their emission rates based on MODIS deep blue aerosol products, Rev. Geophys., 590, RG3005, https://doi.org/10.1029/2012RG000388, 2012.

Grenfell, T., Warren, S., and Mullen, P.: Reflection of solar radiation by the Antarctic snow surface at ultraviolet, visible, and nearinfrared wavelengths, J. Geophys. Res., 99D9, 18669-18684, https://doi.org/10.1029/94JD01484, 1994.

Grenfell, T. C., Doherty, S. J., Clarke, A. D., and Warren, S. G.: Light absorption from particulate impurities in snow and ice determined by spectrophotometric analysis of filters, Appl. Opt., 50, 2037-1048, https://doi.org/10.1364/AO.50.002037, 2011.

Guang-Ming, W., Zhi-Yuan, C., Shi-Chang, K., Kawamura, K., Ping-Qing, F., Yu-Lan, F., Xin, W., Shao-Peng, G., and Bin, L.: Brown carbon in the cryosphere: Current knowledge and perspective, Environ. Sci. Technol., 7, 82-89, https://doi.org/10.1016/j.accre.2016.06.002, 2016.

Gustafsson, O. and Ramanathan, V.: Convergence on climate warming by black carbon aerosols, P. Natl. Acad. Sci., 113, 42434245, https://doi.org/10.1073/pnas.1603570113, 2016.

Hansen, J. and Nazarenko, L.: Soot climate forcing via snow and ice albedos, P. Natl. Acad. Sci., 101, 423-428, https://doi.org/10.1073/pnas.2237157100, 2004.

Hansen, J., Sato, M., Ruedy, R., Nazarenko, L., Lacis, A., Schmidt, G. A., Russell, G., Aleinov, I., Bauer, M., Bauer, S., Bell, N., Cairns, B., Canuto, V., Chandler, M., Cheng, Y., Del Genio, A., Faluvegi, G., Fleming, E., Friend, A., Hall, T., Jackman, C., Kelley, M., Kiang, N., Koch, D., Lean, J., Lerner, J., Lo, K., Menon, S., Miller, R., Minnis, P., Novakov, T., Oinas, V., Perlwitz, J., Perlwitz, J., Rind, D., Romanou, A., Shindell, D., Stone, P., Sun, S., Tausnev, N., Thresher, D., Wielicki, B., Wong, T., Yao, M., and Zhang, S.: Efficacy of climate forcing, J. Geophys. Res., 110, D18104, https://doi.org/10.1029/2005JD005776, 2005.

Hansen, J., Sato, M., Ruedy, R., Kharecha, P., Lacis, A., Miller, R., Nazarenko, L., Lo, K., Schmidt, G. A., Russell, G., Aleinov, I., Bauer, S., Baum, E., Cairns, B., Canuto, V., Chandler, M., Cheng, Y., Cohen, A., Del Genio, A., Faluvegi, G., Fleming, E., Friend, A., Hall, T., Jackman, C., Jonas, J., Kelley, M., Kiang, N. Y., Koch, D., Labow, G., Lerner, J., Menon, S., Novakov, T., Oinas, V., Perlwitz, Ja., Perlwitz, Ju., Rind, D., Romanou, A., Schmunk, R., Shindell, D., Stone, P., Sun, S., Streets, D., Tausnev, N., Thresher, D., Unger, N., Yao, M., and Zhang, S.: Climate simulations for 1880-2003 with GISS, ModelE. Clim. Dyn., 29, 661-696, https://doi.org/10.1007/s00382-007-0255-8, 2007.

He, C., Li, Q., Liou, K.-N., Takano, Y., Gu, Y., Qi, L., Mao, Y., and Leung, L. R.: Black carbon radiative forcing over the Tibetan Plateau, Geophys. Res. Lett., 41, 7806-7813, https://doi.org/10.1002/2014GL062191, 2014.

Hecobian, A., Zhang, X., Zheng, M., Frank, N., Edgerton, E. S., and Weber, R. J.: Water-Soluble Organic Aerosol material and the light-absorption characteristics of aqueous extracts measured over the Southeastern United States, Atmos. Chem. Phys., 10, 5965-5977, https://doi.org/10.5194/acp-10-5965-2010, 2010.

Iacono, M. J., Delamere, J. S., Mlawer, E. J., Shephard, W., Clough, S. A., and Collins, W. D.: Radiative forcing by long-lived greenhouse gases: Calculations with the AER ra- 
diative transfer models, J. Geophys. Res., 113, D13103, https://doi.org/10.1029/2008JD009944, 2008 (code available at: http://rtweb.aer.com/rrtm_frame.html, last access: 3 May 2021).

Jo, D. S., Park, R. J., Lee, S., Kim, S.-W., and Zhang, X.: A global simulation of brown carbon: implications for photochemistry and direct radiative effect, Atmos. Chem. Phys., 16, 3413-3432, https://doi.org/10.5194/acp-16-3413-2016, 2016.

Kirchstetter, T. W. and Thatcher, T. L.: Contribution of organic carbon to wood smoke particulate matter absorption of solar radiation, Atmos. Chem. Phys., 12, 6067-6072, https://doi.org/10.5194/acp-12-6067-2012, 2012.

Kok, J. F.: A scaling theory for the size distribution of emitted dust aerosols suggests climate models underestimate the size of the global dust cycle, P. Natl. Acad. Sci., 10, 274-281, https://doi.org/10.1073/pnas.1014798108, 2011.

Kok, J. F., Ridley, D. A., Zhou, Q., Miller, R. L., Zhao, C., Colette, L. H., Ward, D. S., Albani, S., and Haustein, K.: Smaller desert dust cooling effect estimated from analysis of dust size and abundance, Nat. Geosci., 10, 274-281, https://doi.org/10.1038/ngeo2912, 2017.

Kopacz, M., Mauzerall, D. L., Wang, J., Leibensperger, E. M., Henze, D. K., and Singh, K.: Origin and radiative forcing of black carbon transported to the Himalayas and Tibetan Plateau, Atmos. Chem. Phys., 11, 2837-2852, https://doi.org/10.5194/acp-11-2837-2011, 2011.

Lambe, A. T., Cappa, C. D., Massoli, P., Onasch, T. B., Forestieri, S. D., Martin, A. T., Cummings, M. J., Croasdale, D. R., Brune, W. H., Worsnop, D. R., and Davidovits, P.: Relationship between oxidation level and optical properties of secondary organic aerosol, Environ. Sci. Technol., 47, 6349-6357, https://doi.org/10.1021/es401043j, 2013.

Laskin, A., Laskin, J., and Nizkorodov, S. A.: Chemistry of Atmospheric Brown Carbon, Chem. Rev., 115, 4335-4382, https://doi.org/10.1021/cr5006167, 2015.

Law, K. S., Roiger, A., Thomas, J. L., Marelle, L., Raut, J.-C., Dalsoren, S., Fuglestvedt, J., Tuccella, P., Weinzierl, B., and Schlager, H.: Local Arctic air pollution: Sources and impacts, Ambio, 46, 453-463, https://doi.org/10.1007/s13280-017-09622, 2017.

Lesins, G., Chylek, P., and Lohmann, U.: A study of internal and external mixing scenarios and its effect on aerosol optical properties and direct radiative forcing, J. Geophys. Res., 107, 4094, https://doi.org/10.1029/2001JD000973, 2002.

Lin, G., Penner, J. E., Flanner, M. G., Sillman, S., Xu, L., and Zhou, C.: Radiative forcing of organic aerosol in the atmosphere and on snow: Effects of SOA and brown carbon, J. Geophys. Res., 119, 7453-7476, https://doi.org/10.1002/2013JD021186, 2014.

Lukács, H., Gelencsér, A., Hammer, S., Puxbaum, H., Pio, C., Legrand, M., Kasper-Giebl, A., Handler, M., Limbeck, A., and Simpson, A.: Seasonal trends and possible sources of brown carbon based on 2-year aerosol measurements at six sites in Europe, J. Geophys. Res., 112, D23S18, https://doi.org/10.1029/2006JD008151, 2007.

Mahowald, N. M., Kloster, S., Engelstaedter, S., Moore, J. K., Mukhopadhyay, S., McConnell, J. R., Albani, S., Doney, S. C., Bhattacharya, A., Curran, M. A. J., Flanner, M. G., Hoffman, F. M., Lawrence, D. M., Lindsay, K., Mayewski, P. A., Neff, J., Rothenberg, D., Thomas, E., Thornton, P. E., and Zender, C. S.: Observed 20th century desert dust variability: impact on climate and biogeochemistry, Atmos. Chem. Phys., 10, 10875-10893, https://doi.org/10.5194/acp-10-10875-2010, 2010.

Meredith, M., Sommerkorn, M., Cassotta, S., Derksen, C., Ekaykin, A., Hollowed, A., Kofinas, G., Mackintosh, A., MelbourneThomas, J., Muelbert, M. M. C., Ottersen, G., Pritchard, H., and Schuur, E. A. G.: Polar Regions, in: IPCC Special Report on the Ocean and Cryosphere in a Changing Climate, edited by: Pörtner, H.-O., Roberts, D. C., Masson-Delmotte, V., Zhai, P., Tignor, M., Poloczanska, E., Mintenbeck, K., Alegría, A., Nicolai, M., Okem, A., Petzold, J., Rama, B., and Weyer, N. M., in press, 2019.

Mie, G.: Beiträge zur Optik trüber Medien, speziell kolloidaler Metallösungen, Ann. Phys., 330, 377-445, 1908.

Painter, T. H., Deems, J. S., Belnap, J., Hamlet, A. F., Landry, C. C., and Udall, B.: Response of Colorado River runoff to dust radiative forcing in snow, P. Natl. Acad. Sci., 107, 17125-17130, https://doi.org/10.1073/pnas.0913139107, 2010.

Petzold, A., Rasp, K., Weinzierl, B., Esselborn, M., Hamburger, T., Dornbrack, A., Kandler, K., Schutz, L., Knippertz, P., Fiebig, M., and Virkkula, A.: Saharan dust absorption and refractive index from aircraft-based observations during SAMUM 2006, Chemical and Physical Meteorology, 61, 118-130, https://doi.org/10.1111/j.1600-0889.2008.00383.x, 2009.

Pitari, G., Di Genova, G., and De Luca, N.: A Modelling Study of the Impact of On-Road Diesel Emissions on Arctic Black Carbon and Solar Radiation Transfer, Atmosphere, 6, 318-340, https://doi.org/10.3390/atmos6030318, 2015a.

Pitari, G., Di Genova, G., Coppari, E., De Luca, N., Di Carlo, P., Iarlori, M., and Rizi, V.: Desert dust transported over Europe: Lidar observations and model evaluation of the radiative impact, J. Geophys. Res., 120, 2881-2898, https://doi.org/10.1002/2014JD022875, 2015 b.

Ridley, D. A., Heald, C. L., and Ford, B.: North African dust export and deposition: a satellite and model perspective, J. Geophys. Res., 117, D02202, https://doi.org/10.1029/2011JD016794, 2012.

Rienecker, M. M., Suarez, M. J., Gelaro, R., Todling, R., Bacmeister, J., Liu, E., Bosilovich, M. G., Schubert, S. D., Takacs, L., and Kim, G.-K.: MERRA: NASA's modern era retrospective analysis for research and applications, J. Climate, 24, 3624-3648, https://doi.org/10.1175/JCLI-D-11-00015.1, 2011.

Saleh, R., Marks, M., Heo, J., Adams, P. J., Donahue, N. M., and Robinson, A. L.: Contribution of brown carbon and lensing to the direct radiative effect of carbonaceous aerosols from biomass and biofuel burning emissions, J. Geophys. Res.-Atmos., 120, 10285-10296, https://doi.org/10.1002/2015JD023697, 2015.

Schär, C. and Kröner, N.: Sequential Factor Separation for the Analysis of Numerical Model Simulations, J. Atmos. Sci., 74,14711484, https://doi.org/10.1175/JAS-D-16-0284.1, 2017.

Sinyuk, A., Torres, O., and Dubovik, O.: Combined use of satellite and surface observations to infer the imaginary part of refractive index of Saharan dust, Geophys. Res. Lett., 30, 1081, https://doi.org/10.1029/2002GL016189, 2003.

Skiles, S. M., Painter, T. H., Deems, J., Landry, C., and Bryant, A.: Dust radiative forcing in snow of the Upper Colorado River Basin. Part II: interannual variability in radiative forcing and snowmelt rates, Water Resour. Res., 48, W07522, https://doi.org/10.1029/2012WR011986, 2012. 
Skiles, S. M., Flanner, M., Cook, J. M., Dumont, M., and Painter, T. H.: Radiative forcing by light-abosorbing particles in snow, Nat. Clim. Change, 8, 964-971, https://doi.org/10.1038/s41558-0180296-5, 2018

Sturm, M., Goldstein, M. A., and Parr, C.: Water and life from snow: a trilliondollar science question. Water Resour. Res., 53, 35343544, https://doi.org/10.1002/2017WR020840, 2017.

Tegen, I., Werner, M., Harrison, S. P., and Kohfeld, F. E.: Relative importance of climate and land use in determinating present and future global soil dust emissions, Geophys. Res. Lett., 31, L05105, https://doi.org/10.1029/2003GL019216, 2004.

Tuccella, P.: Radiation absorbing aerosol, OSF, https://doi.org/10.17605/OSF.IO/XNTR8, 2020.

Tuccella, P., Thomas, J. L., Law, K. S., Raut, J.-C., Marelle, L., Roiger, A., Weinzierl, B., Denier van der Gon, H. A. C., Schlager, H., and Onishi, T.: Air pollution impacts due to petroleum extraction in the Norwegian Sea during the ACCESS aircraft campaign, Elem. Sci. Anth., 5, p. 25., https://doi.org/10.1525/elementa.124, 2017.

Tuccella, P., Curci, G., Pitari, G., Lee, S., and Jo, D. S.: Direct radiative effect of absorbing aerosols: sensitivity to mixing state, brown carbon and dust refractive index and shape, J. Geophys. Res., 125, e2019JD030967, https://doi.org/10.1029/2019JD030967, 2020.

Updyke, K. M., Nguyen, T. B., and Nizkorodov, S. A.: Formation of brown carbon via reactions of ammonia with secondary organic aerosols from biogenic and anthropogenic precursors, Atmos. Environ., 63, 22-31, https://doi.org/10.1016/j.atmosenv.2012.09.012, 2012.

Wagner, R., Ajtai, T., Kandler, K., Lieke, K., Linke, C., Müller, T., Schnaiter, M., and Vragel, M.: Complex refractive indices of Saharan dust samples at visible and near UV wavelengths: a laboratory study, Atmos. Chem. Phys., 12, 2491-2512, https://doi.org/10.5194/acp-12-2491-2012, 2012.

Wang, X., Doherty, S. J., and Huang, J.: Black carbon and other light-absorbing impurities in snow across North China, J. Geophys. Res., 118, 1471-1492, https://doi.org/10.1029/2012JD018291, 2013.

Wang, X., Heald, C. L., Ridley, D. A., Schwarz, J. P., Spackman, J. R., Perring, A. E., Coe, H., Liu, D., and Clarke, A. D.: Exploiting simultaneous observational constraints on mass and absorption to estimate the global direct radiative forcing of black carbon and brown carbon, Atmos. Chem. Phys., 14, 10989-11010, https://doi.org/10.5194/acp-14-10989-2014, 2014.

Wang, X., Heald, C. L., Sedlacek, A. J., de Sá, S. S., Martin, S. T., Alexander, M. L., Watson, T. B., Aiken, A. C., Springston, S. R., and Artaxo, P.: Deriving brown carbon from multiwavelength absorption measurements: method and application to AERONET and Aethalometer observations, Atmos. Chem. Phys., 16, 1273312752, https://doi.org/10.5194/acp-16-12733-2016, 2016.
Wang, X., Heald, C. L., Liu, J., Weber, R. J., Campuzano-Jost, P., Jimenez, J. L., Schwarz, J. P., and Perring, A. E.: Exploring the observational constraints on the simulation of brown carbon, Atmos. Chem. Phys., 18, 635-653, https://doi.org/10.5194/acp-18635-2018, 2018.

Ward, J. L., Flanner, G. M., Bergin, M., Dibb, J. E., Polashenski, C. M., Soja, A. J., and Thomas, J. L.: Modeled response of Greenland snowmelt to the presence of biomass burning-based absorbing aerosol in the atmosphere and snow, J. Geophys. Res., 123, 6122-6141, https://doi.org/10.1029/2017JD027878, 2018.

Warren, G. S.: Light-absorbing impurities in snow: a personal and historical account, Front. Earth Sci., 6, 250, https://doi.org/10.3389/feart.2018.00250, 2019.

Warren, S. and Clarke, A.: Soot in atmosphere and snow surface of Antarctica. J. Geophys. Res., 95D2, 1811-1816, https://doi.org/10.1029/JD095iD02p01811, 1990.

Wu, C., Liu, X., Lin, Z., Rahimi-Esfarjani, S. R., and Lu, Z.: Impacts of absorbing aerosol deposition on snowpack and hydrologic cycle in the Rocky Mountain region based on variableresolution CESM (VR-CESM) simulations, Atmos. Chem Phys., 18, 511-533, https://doi.org/10.5194/acp-18-511-2018, 2018.

Ye, H., Zhang, R., Shi, J., Huang, J., Warren, S. G., and $\mathrm{Fu}, \mathrm{Q}$.: Black carbon in seasonal snow across northern Xinjiang in northwestern China, Environ. Res. Lett., 7, 044002 , https://doi.org/10.1088/1748-9326/7/4/044002, 2012.

Zatko, M. C. and Warren, S. G.: East Antarctic sea ice in spring: spectral albedo of snow, nilasm frost flowers5 and slush, and light-absorbing impurities in snow, Ann. Glaciol., 56, 69, https://doi.org/10.3189/2015AoG69A574, 2015.

Zhang, Y., Forrister, H., Liu, J., Dibb, J., Anderson, B., Schwarz, J. P., Perring, A. E., Jimenez, J. L., Campuzano-Jost, P., Wang, Y., Nenes, A., and Weber, R. J.: Top-of-atmosphere radiative forcing affected by brown carbon in the upper troposphere, Nat. Geosci., 10, 486-489, https://doi.org/10.1038/ngeo2960, 2017.

Zhao, S., Jiang, T., and Wang, Z.: Snow grain-size estimation using Hyperion Imagery in a typical area of the Heihe River Basin, China, Remote Sens., 5, 238-253, https://doi.org/10.3390/rs5010238, 2013. 